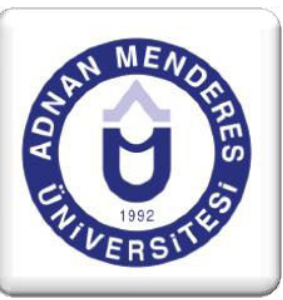

\title{
6360 Sayılı Kanun ve Aydın'a Etkileri
}

\section{Law No. 6360 and Effects on Aydın}

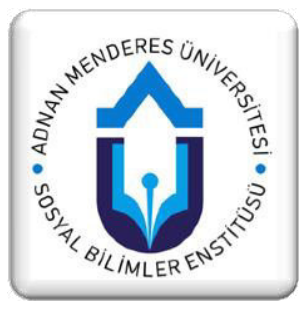

\section{Özet}

Bu makalede, 6360 sayılı yasayla büyükşsehir belediyesi statüsü kazanan Aydın Fatma Neval kenti için yasanın getirdiği yeni durum kamu yönetimi disiplini perspektifinden GENÇ incelenmektedir. Makalede öncelikle 6360 sayll yasa ile getirilen yeni düzenleme ana hatlarıyla incelenmekte ve buna ilişkin değerlendirmeler ele alınmaktadır. Makalede ikinci olarak Aydın kentinin genel özellikleri, kentsel gelişim süreci, kentleşme yapısı üzerinde durulmakta ve ardından 6360 sayılı yasayla büyükşehir olan bu kentsel alanda yeni düzenlemeyle ortaya çıkması muhtemel yönetim sorunları ve çözüm alternatifleri ele alınmaktadır. Ulusal literatür, yerinde incelemeler, birincil ve ikincil veriler ile yerel/bölgesel gazete haberleri, raporlar tespit ve analizler için kullanılmaktadır.

Anahtar Kelimeler: 6360 sayılı yasa, Büyükşehir belediyesi, Aydın

\section{Abstract}

In this article, for the city of Aydin which is gained the status of the metropolitan municipality with the help of Law No 6360, the new state of law is examined from the perspective of public administration discipline. In the article, first the new regulation incidented to the Law 6360 is examined in general terms and related assessments are discussed. Secondly, in the article, general characteristics of Aydın, the process of urban development and urbanization structure are mentioned and then the management problems which are likely to occur with this new arrangement and alternative solutions are discussed. National literature, site visiting, local/national newspaper articles with primary and secondary data

${ }^{*}$ Doç. Dr.

Adnan Menderes Üniversitesi Nazilli Iktisadi ve Idari Bilimler Fakültesi

Siyaset Bilimi ve Kamu Yönetimi Bölümü and reports are used for identification and analyzes.

Keywords : Law No.6360, Metropolitan Municipality, Aydın 


\section{GíRiş}

Türkiye'de 1950'lerden bu yana devam eden kentleşme eğilimi özellikle kent merkezlerinden uzak, plansız yerleşmelerin ortaya çıkmasına ve kentlerin sıçramalı büyüyerek saçaklanmasına neden olmuştur (Genç, 2014). Kentleşmenin dinamik bir süreç olması, yeni ihtiyaçlar ve hizmetler, hızlı kentleşme ve göç olgusu gibi nedenlerle birçok kent çevrelerine, çeperdeki kasaba ve köyler de çekirdekteki en büyük belediyeye/kente doğru büyümektedir. Sonuçta, birkaç köye ilaveten, birden fazla belediye ve köy, bir kentsel alanda tek bir belediye kentsel hizmetleri başarıyla sunamamaktadır. Bu da küçük belediyeleşme ve parçalanmış idari alanlar sorununu gündeme getirmektedir (Özgür, 2008).

Bu türden büyüme şeklinin planlama, hizmet kalitesi, hizmet ölçeğinde optimalitenin aşılması gibi pek çok sorunu ortaya çıkardığı da bir gerçektir. Geçmiş dönemler içinde farklı yasal düzenlemeler yapılarak kentlere ve yerel yönetimlere dair sorunlar aşılmaya çalışılıııstır. Nüfuslarına, büyüklüklerine ve özelliklerine bakmadan tüm belediyeleri aynı kategoride değerlendiren 1580 sayılı eski Belediye Kanunu 1930-2004 arasındaki dönemde yürürlükte kalmıştır. Hızlı kentleşme, kentlerin saçaklanması, küçük belediyeler, plansız metropolleşme, ölçek sorunlarını gidermek amacıyla atılan önemli adımlardan biri de büyükşehir belediyeleri kurmak olmuştur. Anayasanın 127. maddesi yerel yönetimleri il, belediye ve köy halkının mahalli müşterek ihtiyaçlarını karşılamak üzere kurulan kamu tüzel kişileri olarak nitelendirmekte ve Anayasa büyük yerleşim merkezleri için özel yönetim biçimleri getirebilmesine imkan sağlanmaktadır. Anayasanın bu hükmüne paralel olarak ülkemizde büyükşehir yönetimleriyle ilgili ilk temel düzenleme 1984 yılında kanunlaşan 3030 sayılı Büyükşsehir Belediyeleri Kanunuyla yapılmıştır. Söz konusu kanunla bir taraftan büyükşehir belediyeleri yönetiminin hukuki statüsü, hizmetlerin planlı, programl, etkin ve uyum içinde yürütülmesini sağlayacak bir düzenleme yapılmış, diğer taraftan da Ankara, İstanbul ve İzmir İllerinde büyükşehir belediyeleri kurulmuştur. Takip eden yıllarda 1986'da Adana, 1987'de Bursa, Gaziantep ve Konya, 1988'de Kayseri, 1993'te Antalya, Diyarbakır, Erzurum, Eskişehir, İzmit, Mersin ve Samsun ve 2000 yılında da Sakarya büyükşehir statüsü kazanmıştır.

Bu kanunlarla büyükşehirlerin yönetim sorunları kısmen hafifletilebilmiştir. Ancak, yerleşik alanı çok sayıda belediye ve köye dağılarak idari/siyasi açıdan parçalanma yaşanan bazı il merkezleri ile büyük ilçe merkezlerinde ciddi yönetim sorunları yaşanmaya devam etmiştir. 150.000-500.000 arasında belediye nüfusuna sahip olup yakın çevresinde ana belediye ile kuvvetli etkileşim içinde çok sayıda belediye ve köy bulunan il merkezi kökenli orta ölçekli kentsel alanlardan olan Antakya, Aydın, Denizli, Kahramanmaraş, Kırıkkale, Malatya, Manisa, Ordu, Şanlıurfa, Trabzon, Zonguldak, Van kentleri ve Alanya, İskenderun, Marmaris, Kuşadası-Söke, Edremit Körfezi, Bodrum Yarımadası, Bandırma-Erdek-Edincik, NazilliKuyucak-Sultanhisar gibi nüfusu 30.000-300.000 civarındaki büyükçe bir veya birkaç ilçe belediyesi ile onun/onların etrafındaki çok sayıda belediye ve köyle bir bütün oluşturan ilçe merkezi kökenli orta ölçekli kentsel alanlar bunlara örnek olarak verilebilmekteydi (Özgür, 2005: 475; Özgür, 2007: 110).

2003 'te 5019 sayılı kanun ve bunun yanında 5025 ve 5026 sayılı kanunlar da büyükşehir belediyelerinin genişleme süreci açısından önemli girişimlerdir. 2004 yılında büyükşsehir belediyesi yönetimlerinin hukukî statülerinin düzenlenmesi ve buralardaki hizmetlerin plânlı, programlı, etkin, verimli ve uyum içinde yürütülmesi için 5216 sayılı Büyükşehir Belediyesi Kanunu çıarılmış, bu kanunla aynı zamanda İstanbul ve Kocaeli illerinde büyükşehir belediye sınırları il sınırı olarak kabul edilmiştir. 5216 sayı1ı Büyükşsehir Belediyesi Kanunu ile büyükşehirlerin mekansal kapsamı genişletilmiş, belde belediyeleri de sınır içerisine dahil edilmiş; büyükşehir belediyesine yakın ilçe belediyeleri büyükşehir ilçe belediyesi hâline dönüştürülmüş, büyükşehir olmada nüfus ölçütü 750.000'e çıkarılmıştır. Kanuna göre büyükşehir belediyelerinde, mevcut valilik binası merkez kabul edilmek ve il mülkî sınırları içinde kalmak şartıyla, nüfusu bir milyona kadar olan büyükşehirlerde yarıçapı yirmi kilometre, nüfusu bir milyondan iki milyona kadar olan büyükşehirlerde yarıçapı otuz kilometre, nüfusu iki milyondan fazla olan büyükşehirlerde yarıçapı elli kilometre olan dairenin sınırı büyükşehir belediyesinin sınırını oluşturmaktaydı. 2008'de 5747 sayılı Büyükşehir Belediye Sınırları İçerisinde İlçe Kurulması ve Bazı Kanunlarda Değişiklik Yapılması Hakkında Kanunla o dönem mevcut sekiz büyükşehirde ilçe örgütü kurularak ilk kademe belediyeleri ilçe belediyelerine dönüştürülmüş, çeşitli büyükşehirlerde yeni ilçeler kurulmuş ve genişletme anlayışı devam etmiştir (Taşkın ve Deniz, 2013: 643, Arıkboğa, 2013). 
$\mathrm{Bu}$ anlayışın son ürünü 6360 sayılı kanundur. Son düzenlemeyle ölçeğe ilişkin düzenlemelerin yanında büyükşehir sisteminde idari, mali, siyasi ve kamusal hizmetlerin sunumu bakımından önemli değişiklikler olmuştur. 6360 sayılı Kanunla getirilen düzenlemeyle 5216 sayılı kanun başta olmak üzere pek çok kanunda değişiklik yapılmıştır ${ }^{1}$. Bu kanunla 5216 sayılı Kanunun getirdiği yirmi, otuz ve elli kilometrelik dairelerin de dışına çıkılmakta ve il sınırları içinde bulunan bütün ilçe belediyeleri büyükşehir ilçe belediyesi hâline gelmektedir. 6360 sayılı kanun il bazında bütünleşik bir kentsel yönetim anlayışını benimseyen, iki kademeli metropoliten yönetim modelini öngörmektedir.

Bu makalede, öncelikle 6360 sayılı kanun, getirdiği yenilikler ve kanuna yönelik değerlendirmeler ele alınmaktadır. Makalede ikinci olarak 6360 sayılı kanun öncesi ve sonrası Aydın'da ortaya çıkan durumu değerlendirmek için, öncelikle kanun öncesi dönemden itibaren Aydın'da kentleşmeye dair özellikler, kentsel gelişme yapısı, kentleşme sorunları incelenmekte, ardından kanunla ortaya çıkan idari, siyasi ve mali yapılanmaya ilişkin özellikler ve ortaya çıkması muhtemel sorunlar üzerinde durulmaktadır.

\section{6360 SAYILI YASA ve GENEL ÖZELLIKKLERİ}

On Dört İlde Büyükşehir Belediyesi ve Yirmi Yedi İlçe Kurulması İle Bazı Kanun ve Kanun Hükmünde Kararnamelerde Değişiklik Yapılmasına Dair Kanun 06/12/2012 tarih ve 28489 sayılı Resmi Gazete'de yayımlanarak yürürlüğe girmiştir.

Kanun tasarısının gerekçesinde, “...Etkin, etkili, vatandaş odakll, hesap verebilen, katılımcl, saydam ve olabildiğince yerel bir yönetim anlayışının pek çok gelişmiş ülkenin kamu yönetimi reformları için temel ilke ve değerler olarak ön plana çıktı̆̆ı..” saptaması yapılmakta; “...yerel yönetimlerin sürekli biçimde gelişstirilmesi ve etkin hizmet üretme kapasitesine sahip hale getirilmesi gerektĭgi" nden söz edilmektedir. Tasarıya göre, "Büyükşehir sınırları içinde yer alan yerel yönetimler küçük ölçekli planlar yapabilseler de bu planların geniş bir çerçeve içinde bütüncül olarak tüm büyükşehir bölgesini kapsayan ve makro politikaları belirleyen bir çerçeve içinde ele alınmasına ihtiyaç vardır. Belli bir coğrafi alanda çok sayıda yerel yönetimin yetkili olması halinde planlama ve koordinasyonun sağlanamayışı ve ölçek ekonomisinden yeterince yararlanılamaması nedeniyle kaynak israfina yol açılmasından dolayı büyükşehirlere ihtiyaç vardır. Sanayileşme, ulaşım ve çevre gibi artan sorunların hizmet üretme kapasitesi ve yeterli mali kaynaktan yoksun küçük ölçekli mahalli idarelerce çözülmesi mümkün görünmemektedir. Bu durum, kaynakların etkin ve yerinde kullanımını engellemekte, küçük yerleşim birimlerinin yanı sıra nüfusun yoğun olduğu büyükşehirlerde de ciddi yönetim sorunlarına yol açmaktadır. Uygun büyüklükte hizmet üretecek güçlü yerel yönetimlerin olmaylşı, halkın yerel yönetimlerden beklediği kamu hizmetlerinin kaliteli biçimde karşılanamaması ve kamu hizmetlerinin sunumunda koordinasyon eksikliği sorunlarını ortaya çıkarmaktadır. Bu çerçevede yönetim, planlama ve koordinasyon açısından belediye sınırı mülki sınır olacak biçimde optimal ölçekte hizmet üretebilecek güçlü yerel yönetim yapılarının varlığına ihtiyaç duyulmaktadır. Büyükşehir alanında sunulan hizmetlerin tek merkezden yürütülmesi ile ortaya çılkan ölçek ekonomileri sayesinde hizmetlerde etkinlik, koordinasyon ve kalite yükselecek, daha az kaynak ile daha çok ve daha kaliteli hizmet sunulması mümkün hale gelebilecektir. Halihazırda birden fazla merkezden verilen hizmetlerin daha büyük ve ideal ölçekteki bir merkez tarafindan verilmesi birim maliyetler ve kişi başına kamusal harcamaları da azaltacaktır. Bu açıdan değerlendirildiğinde il sınırında hizmet üretecek büyükşehir belediye modeli şu olumlu gelişmeleri ortaya çıkaracaktır; geniş ölçekte hizmet üreten yerel yönetim birimleri gelişmiş teknolojilerle donatılabilecektir; geniş ölçekte hizmet üretecek bu yönetimlerde nitelikli teknik personel istihdam edilebilecek, ayrıca iş gücü uzmanlaşacağından verimlilik artışı sağlanacaktır; geniş ölçekli yerel birimlerden oluşan yerel yönetim sistemi, merkezden gönderilecek kaynakların etkin kullanımını sağlayacaktır; $\mathrm{il}$ sınırları içinde bütünleştirilmiş yerel yönetim birimleri arasında kaynakların kullanımı ve sahip olunacak imkanlar açısından daha adil bir yapı ortaya çıkabilecektir, düzenleyici üst imar planları çerçevesinde il çapında uyumlu imar uygulamaları gerçekleştirilebilecektir. " denilmektedir.

\footnotetext{
${ }^{1} 6360$ sayılı kanınla beraber, 5216 Sayılı Büyükşehir Belediye Kanunu, 5393 Sayılı Belediye Kanunu, 5302 Sayılı İl Özel İdaresi Kanunu, 2464 Sayılı Belediye Gelirleri Kanunu, 5779 Sayılı İl Özel İdarelerine ve Belediyelere Bütçe Vergi Gelirlerinden Pay Verilmesi Hakkında Kanun, 2972 Sayılı Mahalli İdareler Ve Mahalle Muhtarları ve İhtiyar Heyetleri Seçimi Hakkında Kanun, 5682 Sayılı Pasaport Kanunu ve 197 Sayılı Motorlu Taşıtlar Vergisi Kanununda da değişiklikler yapılmıştır.
} 
Kanunla “...Mevcut yerel yönetim yapısı ile yerel nitelikteki kamu hizmetlerinin etkin ve verimli bir şekilde sunulması olanağı kalmayan bazı illerde, bu hizmetlerinin vatandaşların artan beklentilerini karşılayabilecek nitelik ve kabiliyetle donatılmış, ideal ölçekte etkin hizmet sunma potansiyeline sahip yerel yönetimlerce sağlanması öngörülmekte ve bu doğrultuda düzenleme yapılmaktadır.” denilmektedir.

Yeni büyükşehir sistemi idari, mali, siyasi, imar ve planlama düzeni bakımından birçok alanda yapısal değişikliklere yol açmıştır. Yeni kanunla birlikte idari yapıda (Tüzel kişiliklerin kaldırılması, yeni tüzel kişilik ihdas edilmesi, idari bağlılık ve isim değişikliği, birleşme ve katılmalar, sınır değişiklikleri ve yetki bölüşümü), mali sistemde (Yerel yönetimlerin alacağı payların yeniden belirlenmesi ve yeni bölüşüm ilişkileri), siyasal coğrafya (seçim çevrelerinin değiştirilmesi ile birlikte temsil ve katılım boyutunun değişmesi), personel yapısı, hizmet sunumu (Mülki sınırlar ile belediye sınırlarının örtüştürülmesi ile hizmet alanının genişlemesi) ile imar ve planlama düzeninde önemli değişiklikler söz konusu olmuştur (İzci ve Turan, 2013: 119). Dolayısıyla bu yeniden yapılanma süreci yerel yönetimlerin görev-yetki ve hizmet alanlarını değiştirmekte, hizmet üretilen mekânsal yapının yeniden belirlenmesi ile birlikte bu hizmeti sunan kuruluşların yapısı da buna göre yeniden düzenlenmektedir.

Kanunun idari yapılanmada meydana getirdiği bu genel değişikliklerle yasa öncesi ve sonrası durum şu şekilde tablolaştırılabilir:

Tablo 1: 6360 Öncesi Ve Sonrası Yerel Yönetimler

\begin{tabular}{|l|l|l|}
\hline Belediye Türü & $\mathbf{6 3 6 0}$ öncesi & $\mathbf{6 3 6 0}$ öncesi \\
\hline Büyükşehir Belediyesi & 16 & 30 \\
\hline Büyükşehir İlçe & 143 & 519 \\
\hline İl Belediyesi & 65 & 51 \\
\hline İlçe Belediyesi & 749 & 400 \\
\hline Belde Belediyesi & 1977 & 393 \\
\hline İl Özel İdaresi & 81 & 51 \\
\hline Toplam Belediye & 2950 & 1393 \\
\hline Köy & 34.339 & 18.288 \\
\hline
\end{tabular}

Kaynak: http://www.migm.gov.tr/Dokumanlar/devirtasfiye.pdf

6360 Sayılı kanunla getirilen değişiklikler şu genel başlıklar altında özetlenebilir:

- Büyükşehir Belediyesi sınırları il mülki sınırı olarak değiştirilmiştir. Yeni kurulan büyükşehirlere ilaveten Adana, Ankara, Antalya, Bursa, Diyarbakır, Eskişehir, Erzurum, Gaziantep, İzmir, Kayseri, Konya, Mersin, Sakarya ve Samsun büyükşehir belediyelerinin sınırları il mülki sınırları olarak yeniden düzenlenmiştir.

- 14 Yeni Büyükşehir Belediyesi kurulmuştur. Aydın, Balıkesir, Denizli, Hatay, Malatya, Manisa, Kahramanmaraş, Mardin, Muğla, Ordu, Tekirdağ, Trabzon, Şanlıurfa ve Van İllerinde, sınırları il mülki sınırları olmak üzere aynı adla büyükşehir belediyeleri kurulmuş ve bu illerin il belediyeleri büyükşehir belediyesine dönüştürülmüştür. Büyükşehir belediyesi kurulan illere bağlı ilçelerin mülki sınırları içindeki köylerin ve belde belediyelerinin tüzel kişilikleri kaldırılmıştır. Yeni Büyükşehir belediyesi olan tüm bu illere bağlı ilçelerin mülki sınırları içerisinde yer alan köy ve belde belediyelerinin; İstanbul ve Kocaeli il mülki sınırları içerisinde bulunan köylerin tüzel kişiliği kaldırılarak bağlı bulundukları ilçe belediyesine mahalle olarak katılmıştır. Böylelikle bu yeni büyükşehirlerde toplamda 1578 belde, 16.544 köyün tüzel kişiliği ortadan kaldırılmıştır. Toplam 30 büyükşehirdeki 1.053 belde belediyesi ile 16.082 köy, mahalle haline getirilmiştir. 
- $\quad$ Büyükşehir belediyesi kurulan illerde köyler mahalleye dönüştürülmüş ve mahalle kurulmasında 500 nüfus ölçütü getirilmiştir.

- $\quad$ Büyükşehir belediyesi kurulan illerde belde belediyeleri mahalleleriyle birlikte belde ismiyle (tek mahalle olarak) bağlı bulundukları ilçenin belediyesine katılmıştır. Tüzel kişiliği kaldırılarak köye dönüşen belediyelerin komşu oldukları il, ilçe ve nüfusu 2.000'in üzerindeki belde belediyelerine, belediye meclisi kararı ile mahalle olarak katılmalarına imkan sağlanmıştır.

- Büyükşehir belediyesi kurulmayan diğer illerde nüfusu 2000'in altında olan belde belediyeleri kaldırılmıştır. Büyükşehir yapılan illerin dışında kalan 51 ilde, nüfusu 2000'den az olan belediyeler kapatılarak köye dönüştürülmüştür. Bu hükümle toplam 502 belediye tüzel kişiliğini yitirmiştir.

- $\quad$ Büyükşehir belediyesi kurulan illerde il özel idarelerinin tüzel kişilikleri kaldırılmış, bunların yerine bu 30 ilde Yatırım Destek Koordinasyon Merkezi (YDKM) kurulmuştur. Valinin başkanlık edeceği bu merkezlerin kalkınma faaliyetlerini, kamu harcamalarını, kamu ve özel yatırımları yönlendirme, ili tanıtma, afet ve acil yardım hizmetlerini koordine etme ve yönetme, ildeki kamu kurum ve kuruluşlarının koordineli çalışmasını sağlama ve denetleme görevleri vardır. Genel bütçe vergi gelirleri tahsilatının \%0,25'lik kısmı nüfus da dikkate alınarak YDKM'ne aktarlacaktır.

- $\quad$ Büyükşehir belediyesi kurulan illerde bucak ve bucak teşkilatları kaldırılmıştır.

- Büyükşehir belediyesi kurulan illerde yeni ilçeler kurulmuştur. Büyükşehir Belediye sınırları içinde $25(25+2)^{2}$ yeni ilçe $e^{3}$ kurulmuştur.

- $\quad$ Büyükşehir belediyesi kurulan illerde mahalli idare birlikleri kaldırılmıştır.

- $\quad$ Büyükşehir belediyesi kurulan illerde kimi yerleşim birimlerinin isimleri değiştirilmiştir.

- Genel bütçe vergi gelirleri tahsilatından belediyelere aktarılan paylar yeniden düzenlenmiştir. Buna göre Genel Bütçe Vergi Gelirleri Tahsilatı Toplamından (GBVGTT) büyükşehir belediyeleri dışındakilere verilen pay \% 2,85 ten \%1,5'e ve il özel idarelerinin payı da $\% 1,15$ ten $\% 0,5$ 'e düşürülmektedir. Ancak 5779 sayılı yasa gereği genel bütçe vergi gelirleri toplamından büyükşehir belediyelerine verilen pay, $\% 2,5$ 'ten $\% 4,5$ 'e yükseltilmekte; yine bu kanuna göre büyükşehir belediye sınırları içinden toplanan genel bütçe vergi gelirleri tahsilat toplamından büyükşehir belediyelerine ayrılan pay da \%5'ten \%6'ya çıkarılmaktadır. GBVGTT içinde büyükşehir ilçe belediyelerine ayrılan payın \%30'u da nüfus ve yüzölçümü temelinde büyükşehir belediyelerine aktarılmaktadır. İlçe belediyelerinden toplanan otopark gelirlerinin de büyükşehir belediyesine aktarılması öngörülmektedir. $\mathrm{Bu}$ şekilde büyükşehir belediyeleri ve bu belediyelerden ilçe belediyelerine ayrılan paylar artırılırken, büyükşehir olmayan illerdeki belediye ve il özel idarelerinin payları azalmaktadır (Batman ve Gül, 2013: 35). Büyükşehir Belediyelerine ayrılan paylardan doğrudan hesaba aktarılacak pay oranı değişmiştir. Kalan kısmın büyükşehir belediyelerine dağıtımında nüfus kriterine ek olarak yüzölçümü kriteri getirilmiştir. Bu \% 6'lık büyükş̧ehir belediye payının \% 60'1 doğrudan ilgili büyükşehir belediyesine aktarılırken, kalan \%40'lık kısmının \%70'i nüfusa, \% 30'u yüzölçümü esasına göre büyükşehir belediyeleri arasında dağıtılmaktadır.

- $\quad$ İlçe ve birinci kademe belediyeleri 5215 Sayılı Belediye Kanunu ile kendilerine tanınan, mevzii imar planı uygulamaları, katı atık toplama ve depolama, mezarlıkların bakım onarım ve defin işlemleri, çevre dokusunu koruma, sosyal etkinlikler v.s. dışında kalan imar uygulaması ve değişiklikleri, toplu taşıma hizmetleri, plaka sınırlaması, tesisleri işletme, kiraya verme, reklam gelirleri ve her türlü fiyat tespit ve ayarlamaları da dâhil yetkileri büyük şehre devredilmiştir. 


\section{6360 SAYILI KANUNA YÖNELİK DEĞERLENDİRMELER}

6360 sayılı kanun getirdiği bu temel değişikliklerle hem olumlu hem de olumsuz eleştirilere maruz kalmaktadır. Kanuna yönelik olumlu değerlendirmeler şu şekilde gruplandırılabilir;

- Optimal ölçek: Kanun, yönetim kademelerinin azaltılması açısından “optimal ölçek” konusunda çağdaş dünyadaki eğilimlere uygun düşmektedir (Parlak, 2013) ${ }^{4}$.

- İmar bütünlüğü sağlama: Kanunun, il sathında bir "imar bütünlüğü" nün sağlanmasını kolaylaştıracağı düşünülmektedir. Ersoy’a göre (2013); 6360 sayılı kanunun verdiği yetki ile bir ilin kapsadığ1 alan bütününün tek bir otorite tarafından üst ölçekli planlarının yapılarak, küçük bölümlerinin birbirinden kopuk ve parçalı biçimde ele alınmasının önüne geçilmesi planlama ilkeleri açısından yerinde bir yaklaşımdır. Kent-bölgeler ya da kentlerin kendi başlarına birer varlık olmadıkları, çevre ve bölgeleri ile yoğun bir ilişki içinde oldukları bilinmektedir. Bu çerçeveden bakıldığında, yeni düzenlemenin il düzeyinde planlama faaliyetlerini bir bütünlük içinde, tek bir otoritenin eşgüdümünde götürülmesinin, aynı il sınırları içinde parçacı, birbiriyle uyumsuz ya da çelişen, eşgüdüm içinde hazırlanmamış, dar yerel çıkar ve beklentilerle, farklı yerel birimler tarafından hazırlanmış çok sayıda planın varlığından daha olumlu olacağı düşünülmektedir. Parçalı uygulamalar yerine vilayetin tümünü, gerekli bütün verileri görerek ve yerleşim yerlerinin gelişim akslarını birlikte düşünerek yapılacak bir imar planlaması daha sağlıklı ve kalıcı olabilecektir. Diğer yandan büyük alan yönetimi, il düzeyinde fiziki planların yanı sıra ekonomik, sosyal ve kültürel planlamaları da içeren bir "tümleşik stratejik plan" yapılması için de verimli bir zemin sunmaktadır. Keleş (2012b) yeni yasayla getirilen düzenlemeler arasında en rahat savunulabilecek olanının imar ve planlamadaki birlik ve bütünsellik kuralı olduğunu ifade etmektedir.

- Önceki düzenlemelere göre avantajları: Mekânsal planlama çerçevesinden bakıldığında, il sınırlarının her ne kadar mülki yapılanma gibi başka bir alanın yaklaşım ve anlayışı ile oluşturulan sınırlar oldukları ileri sürülse de, büyükşehir sınırlarını belirlemekte daha önce geçerli olan ve herhangi bir araştırma ve değerlendirmeye dayanmayan "pergel yasası" ile getirilen kurala göre daha anlamlı olduğu belirtilmelidir.

- Verimlilik ve etkinlik artışı beklentisi: Kanunun gerekçesinde de belirtildiği şekilde köyden mahalleye dönüşen yerlerin alt yapı hizmetleri için belediye ve bağlı yönetimlere yatırım bütçelerinin \%10'unu 10 yıl süreyle ayırma zorunluluğu getirilerek bu yerlerde etkin hizmet yürütme ve yeni yatırımlar yapabilme olanağının getirilmesi de yararlı bir yöntem olarak görülmektedir.

Diğer yandan yasaya yönelik ciddi eleştiriler de yapılmaktadır. Bu eleştiriler şu şekilde sıralanabilir;

- Anayasaya aykırılık: Anayasa değişikliği yapılmadan il özel idareleri, köyler ve belde belediyelerinin tüzel kişiliklerinin kanunla kaldırılması, ilçe belediyelerinin büyükşehir ilçe belediyesi hâline dönüştürülmesi Anayasaya aykırıdır. Anayasa (m.127/3), "özel yönetim biçimlerinin kurulmasına "büyük iller" için değil, ancak "büyük yerleşim merkezleri" için izin vermiştir. Birbirinden 80-90 kilometre uzakta olan yerleşim yerleri bir "yerleşim merkezi" oluşturamayacağı gibi, nüfusu 100.000'i bile aşmayan il merkezlerinin birer "büyük yerleşim merkezi” oldukları da iddia edilemez. Örneğin büyükşsehir belediyesi kurulan Muğla'nın merkez nüfusu 62.635, Mardin'in merkez nüfusu 88.054'tür. Anayasa, mahallî idareler için il özel idaresi, belediye ve köyden oluşan bir çerçeve öngörmüştür. Bu çerçevenin dişına taşan bir mahallî idare reformu yapılmak isteniyorsa, öncelikle Anayasa değişikliği yapılmalıdır. Bir il kaldırılmadıkça o ildeki il özel idaresinin kanunla kaldırılması anayasaya aykırıdır. Köy tüzel kişiliğinin kaldırılıp bir şehrin mahallesi hâline dönüştürülmesi ancak şehir merkezine yakın olup, aşırı şehirleşme sonucunda zamanla şehirle bitişmiş ve fiilen bu şehrin mahallesi hâline gelmiş bir köy veya belde için sözkonusu olabilir. Köy halkının mahallî müşterek ihtiyaçlarının karar organları kendisi tarafından seçilen köy idaresi yerine bir başka idare tarafından karşılanması; köyün bir belediyenin mahallesi hâline dönüştürülmesi, köy halkının mahalli müşterek ihtiyaçlarını karş1layacak

\footnotetext{
${ }^{44}$ http://www.bursayerelyonetim.com/index.php/yeni-buyuksehir-belediyeyasasininanalizi/\#sthash.jbyElZdC.dpuf
} 
kamu tüzel kişilerinin karar organlarını seçme hakkını kaybettiklerinden anayasaya aykırıdır. Anayasa, il, belediye ve köy halkının mahallî müşterek ihtiyaçlarını tek bir mahallî idare tarafından değil, "mahallî idareler" tarafından karşılanmasını öngörmüştür. Bu nedenle il, belediye ve köy halkının mahallî müşterek ihtiyaçlarını karşılamak için sadece tek bir tür mahallî idare (belediye) kurulması anayasaya aykırılık yanında tektipleşmeye de neden olacaktır. Oysa 6360 sayılı Kanunla 30 ilde bir yandan il özel idareleri, diğer yandan da köylerin tüzel kişiliği kaldırılmıştır (Gözler, 2013).

- İlçe belediyelerinin özerkliğini yitirmesi: $\mathrm{Bu}$ otuz ilde bütün ilçe belediyelerinin büyükşehir ilçe belediyesi hâline dönüşmesi bu ilçelerin özerkliğini çok büyük ölçüde yitirmesi anlamına gelmektedir. Eski ilçe belediyelerinde artık bazı hizmetler büyükşehir belediyesi tarafindan yürütülmekte ve bazı konularda karar alma yetkisi büyükşehir belediyesine geçmekte ve ilçe belediyesinin bazı kararları da büyükşehir belediyesinin onayına tâbi olmaktadır. Şehir merkezinden 80-90 kilometre uzaklıkta olan ve yerleşim yerlerinin birleşme ihtimali olmayan ilçe belediyelerinin de büyükşehir ilçe belediyesi hâline dönüştürülmesinin Anayasa m.127/3 ile bir ilgisi yoktur (Gözler, 2013).

- Yetki ve görev uyuşmazlıklarının ortaya çıkması: Yerel yönetim sistemimizde il özel idaresi, belediye ve köy arasında ince bir görev ve yetki paylaşımı vardır. Bu paylaşım, yüzyıllık bir mevzuatın ürünüdür. $\mathrm{Bu}$ ilkelerin kaldırılması öngörülmeyen yetki ve görev uyuşmazlıklarını ortaya çıkarabilir. Özellikle büyükşehir belediyelerinin sınırlarının il sınırları olması, yani il sınırları içindeki bütün arazinin büyükşehir belediyesinin görev ve yetki sahasına sokulması uygulamada pek çok konuda yetki çatışması sorununa yol açabilir. Diğer yandan plan yapımında yetki karmaşasının ortaya çıkması muhtemeldir. Bugün 14'ü merkezi olmak üzere toplam 19 kamu kurum ve kuruluşu kendi ilgi konularına ilişkin alanlarda plan yapma yetkisine sahiptir ${ }^{5}$ ve bu şekilde yapılan mekânsal plan sayısı da 61'dir. Bu kurumsal karmaşa 6360 sayılı yasa ile belirlenen planlama sınırları temel alındığında yeni sorunları da beraberinde getirebilecektir (Ersoy, 2013).

- İkili yapı: 6360 sayılı kanunda 30 büyükşsehir belediyesinde il özel idareleri kaldırılmış; diğer illerde ise il özel idarelerinin varlıkları korunmuştur. Böylece il özel idareleri bakımından il özel idareli iller ve il özel idaresiz iller olmak üzere ikili bir yapı ortaya çıkmıştır. Büyükşehir belediyesi kurulan illerde il özel idarelerinin görev, yetki ve kaynakları, taşınır ve taşınmaz malları, yetkileri karmaşık biçimde bakanlıklara, bağlı ve ilgili kuruluşlara, taşra teşkilatına, valiliklere, hazineye, büyükşehir belediyelerine ve onların bağlı ve ilgili kuruluşlarına ve ilçe belediyelerine verilmiştir.

- Bölge-Kent Oluşumu: Düzenlemenin İstanbul, Kocaeli, İzmir, Bursa, Eskişehir, Adana, Sakarya ve Aydın gibi görece oldukça kentleşmiş ve gelişmiş illerde gözlenen kentsel alan oluşum süreçleriyle örtüşen ve katkı sağlayan bir şekilde olduğu söylenebilir. Ancak Konya, Manisa, Van, Şanlıurfa, Erzurum, Antalya, Mersin, Balıkesir gibi coğrafi olarak çok geniş alana yayılan ve görece kırsal alanları daha fazla olan illerin kentleştirilmeye çalışıldığ 1 ve yeni bir bölge-kent oluşturma denemesine girişildiği söylenebilir (Gözler, 2013, İzci ve Tuıran, 2013: 128, 135). $50 \mathrm{~km}$ yarıçap1 olan büyükşsehir belediyelerinde bile çeperlerindeki yerleşim yerlerine hizmet götürmede darboğazlar yaşanırken, yeni düzenleme ile merkezden 250-300 km uzaktaki birimlere nasıl hizmet götüreceğinin güvencesi yoktur (Keleş, 2012a: 11; Gül ve Batman, 2013: 35). 6360 sayılı kanun, il sınırı dışındaki hinterlandı ile işlevsel ilişkileri bulunan alanı bütünlüğe dahil etmemektedir. $\mathrm{Bu}$ anlamda modelin doğrudan kent-bölge yönetimleri oluşturmak gibi bir hedefi olduğunu söylemek zor olmakla beraber, zaman içerisinde özellikle 1. grup illerde kent-bölge oluşumunu tetiklemesi ya da desteklemesi ve kentlerin büyüme şeklini yönlendirerek kent-bölge oluşumlarını hızlandırması söz konusu olabilecektir.

- Yeni büyükşehirlerin imkan ve kaynaklarının standart olmaması: Büyükşehir belediyelerinde yeterli kaynakların, araç-gereç ve donanımın, yeterli sayıda nitelikli kadroların varlığını gerekli kılmaktadır. Bunların sağlanması ve etkin olarak kullanılması kısa vadede zorken, görece geri kalmış yörelerimizde

\footnotetext{
5 Yürürlükte olan mevzuata göre, il düzeyinde üst ölçekli planlar şöyle sıralanabilir: 1) Kalkınma Bakanlığı ve Kalkınma Ajansları tarafından hazırlanan Bölge Planları; 2) Çevre ve Şehircilik Bakanlığı tarafından hazırlanan birden çok ili kapsayan Çevre Düzeni Planları; 3) İl Çevre Düzeni Planları 4) Büyükşsehir belediyeleri tarafından hazırlanan 1/25.000 ölçekli nazım imar planları.
} 
büyükşehir belediyelerinin tüm il sahasında etkin ve başarılı olmalarının kolay olmayacağı beklenmektedir (Keleş, 2013: 18).

- Artan hizmet maliyeti: İl ve ilçe merkezi arasında uzaklığ fazla olan illerde hizmet maliyetine ek olarak ulaşım maliyeti de eklenecektir. Bunun yanında İstanbul, İzmir, Ankara gibi büyük nüfuslu kentlerde de hizmet maliyetine kalabalıklaşma/yoğunlaşma maliyetinin de eklenmesiyle hizmet maliyetinin artacağı beklenmektedir (Yıldırım ve Belli, 2013: 109). Diğer yandan sınırları genişletmenin ekonomik, toplumsal, çevresel sonuçları da olabilecektir (Keleş, 2013: 18).

- Belediyelerin kırsal alana hizmet götürmesinde karşılaşabileceği güçlükler: Mevcut belediye hukuku, il ölçeğini yönetmeye uygun değildir; belediye, kentsel yerleşimlerin yönetimidir, il ve ilçelerdeki kırsal yerleşmelere hizmet vermek için hem coğrafi şartlar hem belediyelerin ekonomik özellikleri ve imkanları uygun değildir. Belediyelerin kırsal yerleşmelerden alabileceği ilan-reklam, tabela, eğlence vb. vergi geliri yoktur, belediyeler hayvanc1llk sektörünü yönetecek yetki ve kapasiteye sahip değildir (Güler, 2012a: 4-5; Çukurçayır, 2012, Turan ev İzci, 2013: 128). Şehir ve sokaklar için uzmanlaşmış bir idare olan belediye idaresinin araç parkı ve personelinin dağ köylerinde hizmet vermesi muhtemelen güç olacaktır. Hukuken bir șehrin mahallesi hâline dönüșen köy halkının neye ihtiyacı olup olmadığına (yol, çeşme, ahır, mera vb) onlarca kilometre ötede olan belediye meclisi karar verecek; belediyenin personeli ve aracıyla yapmaya çalışacaktır. Böyle bir sistem, yerel demokrasi, rasyonalite ve optimalite açısından da sıkıntılı olduğu gibi, bazı durumlarda israfa neden olabilecek, belediyelerin altyapı maliyetleri artabilecektir. Köyler mahalleye dönüşünce köylerdeki araziler emlak vergisine tâbi hâle gelecektir. Kanun bu gibi yerleri sadece beş yıl süreyle vergiden istisna tutmuştur. Diğer yandan il sınırları da en uygun planlama alanı olarak kabul edilemez. Çünkü bazı büyükşehirler için (İstanbul gibi) ilişkiler ağı küresel ölçeğe dek uzarken bazıları için il sınırları içindeki tüm yerleşmeleri dahi kapsamayacak kadar sınırlı kalabilir (Mardin ve Şanlıurfa gibi). Böyle bakıldığı zaman "yerel" düzeyde planlama sınırlarının zamansal ve mekansal olarak büyük değişiklik göstereceği, bu nedenle de herhangi bir zaman aralığında bile "ideal" olarak tanımlanabilecek bir ölçüden söz edilemeyecektir. 5216 sayılı Kanunda büyükşehir belediyesi nazım planlarının hazırlanması, ilçe belediyeleri ise uygulama imar planlarının hazırlanması konusunda yetkilendirilmişlerdir. Keleş’e göre (2012b), "bu paylaşım yöntemi iki basamak arasındaki uyuşmazlıkların giderilmesine katkıda bulunmadığ gibi; bunun, ilçe belediyelerinin bir yerel yönetim birimi olarak sahip olmaları gereken özerklikle bağdaşmamaktadır." Yeni düzenleme imar ve planlama hizmetleri konusunda kimi üstünlüklere sahip ise de diğer büyükşehirlerin hem nüfus hem de kapladıkları alan bakımından farklılıkları da gözönünde bulundurulmalıdır. Dolayısıyla büyükşehire uzak olan yerleşim birimlerine hizmet sunumu bu bakımdan bu düzenleme etkin ve verimli olmayacaktır. İmar planlarının uygulama ve denetim araçlarının kullanılması bakımından coğrafi uzaklık hizmetin etkin ve verimli sunulmasını olumsuz etkileyecektir (Keleş, 2012b). Ülkemizdeki büyükşehir belediyelerinin bu radikal değişime ne derecede hazır oldukları da bir başka sıkıntılı konudur. Modelin önceden denendiği, kentsel hizmetlerin sunumu ve koordinasyonunda gereken yapılanmanın mevcut olduğu Kocaeli ve İstanbul örnekleri ülke geneli için tümüyle geçerli olamaz. Yeni kurulacak büyükşehirlerin büyük bölümünde koordinasyon gerektirecek hizmet bütünlüğünü zorunlu kılan fiziki koşullar bulunmamaktadır. Diğer yandan bu büyükşehirlerdeki köyler için sahipsiz kalma, tarım ve hayvancılığın tehlikeye girmesi, kırsal arazilerin kentsel arazilere dönüşmesi gibi sorunlar da ortaya çıkabilecektir (Duru, 2013: 35).

- Büyükşehir ölçeğinin optimal olmaması: YAYED'e (2012) göre büyükşehir ölçeğinin siyasal, toplumsal, yönetsel olarak optimal ölçek olamayacağ1 gibi ekonomik olarak da optimal olup olmadığ 1 tartışmalıdır. Neden 1 veya 2 milyon değil de 750.000 nüfusun ölçüt alındığı belli değildir (Keleş, 2013: 18). Büyükşehir olan bu iller içinde Hatay'da İskenderun, Muğla'da Fethiye, Mardin'de Kızıltepe ve Nusaybin gibi bazı ilçe belediyeleri, il nüfusuna yakın veya daha fazla nüfusa sahiptir. Ancak yeni düzenlemeyle daha önce kullandıkları pek çok yetkiyi büyükşehir belediyesine devretmek durumundadır (Duru, 2013: 34). Ana Muhalefet Partisi'nin Alt Komisyon Raporu'na karşı hazırlamış olduğu muhalefet şerhinde, mülki sınırların mahalli hizmetler için optimal ölçek sayılamayacağı, sınırları siyasi ve idari ölçütler ile belirlenen mülki yönetim ile sınırları yerel nitelikli hizmetler ölçütüne göre belirlenen mahalli yönetimin hizmet ve yönetim ölçütlerinin birbirinden farklı olduğu savunulmaktadır (Güler, 2012b). Güler'e göre, sözkonusu optimalite amacına ulaşmak için yeni bir kanuni düzenleme yerine yerel 
yönetim birlikleri yeniden düzenlenerek de etkin olarak kullanılabilir. Her kentin hizmet maliyeti ve o kentte elde edilen marjinal fayda farklıdır. 5393 sayılı kanuna göre belediye kurma ölçütü 5000 dir. Ancak 5000-750.000 arası, çok geniş bir nüfus aralığını kapsamaktadır. Bu geniş nüfus aralığı içinde orta büyüklükteki/ölçekli kent türü tamamen göz ardı edilmiş, kent nüfusu kent ve büyükşehir olmak üzere iki grup altında değerlendirme gibi hatalı bir sonuca yol açmaktadır. 5000-750.000 arasında nüfusa sahip kentler için ayrı bir bilimsel düzenlemeye ihtiyaç vardır. Özellikle nüfusu 100.000-750.000 arasında olan kentlerde bilimsel ölçütler dikkate alınarak orta büyüklükteki kentler kavramı da mevzuattaki yerini almalıdır (Yıldırım ve Belli, 2013: 105, 109). Çukurçayır da (2012) optimal ölçeğin literatürde 50 binle sınırlandırıldığından yola çıkarak, nüfus kriterinin 750 bine çıkarılmasının uygun olmamasından söz etmektedir. Diğer yandan ölçeğin büyümesinin maliyetleri azaltacağı da her zaman geçerli değildir. Tüm belde ve ilçelerin kimliklerini yok etmek yerine orta ölçekli kentsel alan gruplandırması yapmak gerekmekte, 100 bin ile 750 bin arasındaki kentlerin sinıflandırılarak il düzeyinde bir model uygulanmalıdır.

- Demokratik katılımın zayıflaması: Yeni yapı ile demokratik katılım imkan ve mekanizmalarının azalacağı da belirtilmektedir (Güler, 2012b; İzi ve Turan, 2013: 136). Büyükşehir meclislerinin daha yoğun bir program yüküyle karşı karşıya kalması ile yerel siyasette katılım mekanizmalarının daha yavaş işlemesi sonucu ortaya çıkabilecektir (Koyuncu, Köroğlu, 2012: 7-8). Düzenleme ile ölçeğin büyütülmesinin temsil ve katılımı zorlaştırdığı, aslında bu yeni yapının ilçe ve alt kademe belediyelerinin tüzel kişiliklerini sınırlayan, belediye başkanının öne çıktığı ve belediye meclislerinin demokratik işlevini azaltan, bu anlamda merkeziyetçiliği öngören bir yap1 oluşturmaya yönelik olduğu belirtilmektedir (Görmez, 2012). Keleş de (2012b, 2013: 18) bu düzenleme ile merkeziyetçiliğin yerel düzeyde güçlendirildiğini, özellikle gelir paylaşımındaki değişikliğin bu duruma örnek olduğunu ve bu düzenlemenin yerelleşme söylemleri ile bağdaşmadığını belirtmektedir. Yerel yönetimlerin varlığına bir yasal düzenleme ile son verilmesi ve taraf olduğumuz Avrupa Yerel Yönetimler Özerklik Şartı'nda yer alan yerel yönetimlerin sınırlarının değiştirilmesinde onlara referandum yoluyla danışılmadan değişiklik yapılamayacağı hükmüne ve temel haklar ve özgürlüklerle ilgili düzenlemelere de aykırı bulunmaktadır (Keleş, 2012b; Keleş, 2013: 19, Görmez, 2012, Duru, 2013: 34). Yerel yöneticilerin yetki ve sorumlulukları artarken merkezden uzaklaştıkça halkın seçtiği kişilere olan mesafesi de artacağından hizmete yerellikten söz etmek de güçleşebilecektir (Yıldırım ve Belli, 2013: 107). Karar mekanizmalarına vatandaşın katılımını daha etkin kılmaya çalışırken, katılım mesafesi ve kolaylığı zora dönüştürecektir.

- Temsil sorunları: Mevcut sistem içinde il genel meclislerinde olduğu gibi büyükşehir belediye meclislerinde de nüfusu az olan ilçelerin temsil oranı daha yüksektir. $\mathrm{Bu}$ da meclis üyelerin temsil ettikleri nüfus büyüklüklerinden farklılaşmalarına neden olmaktadır. Ölçeğin büyümesiyle birlikte çok sayıda nüfusu az ilçeden gelen meclis üyesinin olacağı düşünüldügünde temsil açısından sorun ortaya çıkabilecektir (Bulut vd, 2013: 154; Arıkboğa, 2007).

- Seçim çevrelerinin değişmesi: Kanunla değişen idari yapılanmaya bağlı olarak seçim çevreleri ve seçmen yapıları da değiştirilmiştir. Bu nedenle düzenlemenin yerel seçim sonuçlarını iktidar partisi lehine etkilemeye yönelik olduğu eleştirileri yapılmıştır. Ankara ve İstanbul'da, kıyı belediyelerinde yapılan düzenlemelerin, İstanbul'da Şişli'ye bağlı Ayazağa, Maslak, Huzur Mahallelerinin Sarıyer'e bağlanmasının iktidar partisinin seçimi kazanmaya yönelik hamlesi olduğu eleştirileri yapılmıştır (İzci ve Turan, 2013: 130, 135). Kanunla, seçim çevresi büyükşehir belediye başkanlığg açısından ilin tamamı olmuştur. Büyükşehir belediye meclisi ise belediye hudutları içinde kalan ilçe seçim çevreleri için tespit edilen belediye meclisleri üye sayısının her ilçe için beşte biri alınmak suretiyle bulunacak toplam sayı kadar üyeden oluşmaktadır. Bu sayıların ne olacağı ise oluşturulacak olan ilçelerin nüfuslarına göre ortaya çıkacaktır. Yapılan değerlendirmelere göre, 2009 yerel seçimlerinde 16 büyükşehir belediyesini kazanan iktidar partisinin yeni düzenleme ile 29 büyükşehir belediyesinin 20'sinde seçimleri kazanabileceği, bu durumda iktidar partisinin daha önce kazanamadığ 1 beş ilde (Adana, Eskişehir, Balıkesir, Manisa, Şanlıurfa) büyükşehir belediye başkanlığını kazanacağı tahmin edilmişti. Bu illerden üç tanesinin (Adana, Balıkesir, Manisa) belediye başkanlığı MHP'nin, biri (Eskişehir) CHP'nin elinde bulunmaktaydı. Mardin ise iktidar partisinin kaybedeceği belediye olarak görülmekteydi. Nihayetinde yeni düzenleme ile MHP'nin 3 ilde belediye başkanlığını kaybederek, CHP'nin de kırsal oy kıskacına 
düşerek olumsuz etkileneceği, DP'nin Mardin'den dolayı olumlu etkileneceği, AKP'nin büyükşehir belediyelerinin 20'sinde seçimi kazanacağ için olumlu etkileneceği belirtilmekteydi (Tüzün, 2012). Ancak 2014 yerel yönetim seçim sonuçları tahmin edilen şekilde olmadı, Adana Büyükşehir Belediyesinde MHP, Eskişehir'de CHP, Manisa'da MHP, sadece Balıkesir ve Şanlıurfa'da AKP büyükşehir belediye başkanlıklarını kazandı.

- Bölge Yönetimine/Federal Yapıya Geçişin Hazırlıkları: İl özel idarelerinin kaldırılmasıyla valilerin taşradaki konumları zaafa uğramakta, valiler, seçilmişler karşısında ikincil konuma düşmektedir (Keleş, 2012: 11). Bir yandan büyükşehir belediye sinırları genişletilirken, diğer yandan YİKM'nin kurularak valiliklerin güçlendirilmesi de tezat bir duruma işaret etmektedir. Merkezden yönetim esasına dayanan ilin, yerinden yönetim esasıyla yönetilmesi durumunda bölge yönetimine dönüşeceği eleştirisi de yapılmaktadır (Güler, 2012a:3-4; İzci ve Turan, 2013: 135). Yasanın bölge yönetimleri oluşturmaya yönelik olduğu, başkanlık sisteminin alt yapısını oluşturmak üzere çıkarıldığı, yerelde güçlü bir merkezileşmeye yol açacağ 1 ve nihayetinde düzenlemenin iktidar partisinin yerel seçimleri kazanmaya yönelik bir stratejisi olduğu yönünde farklı bakış açıları bulunmaktadır. İl özel idarelerinin kaldırılmasıyla birlikte bölge yönetimlerinin kuruluş sürecinin başladığı, tüm ili kapsayan belediye sistemi ile başkanlık sistemine geçişin öngörüldüğü, illerin merkezden yönetim esası yerine yeniden yönetim esasına göre yönetilmeye doğru kaydırıldığı, bu değişiklikle federal devlet yapılanmasının oluşturulmaya çalışıldığı da ifade edilmektedir (Güler, 2012b; Çukurçayır, 2012). Buna karşıllk düzenlemenin bir bölge yönetimi, federasyon denemesi, siyasi özerklik gibi amaçlar taşımadığını ifade edenler de vardır (Görmez, 2012; Keleş, 2012b).

- Vergi tabanının farklılaşması: Yeni büyükşehirlerde vergi tabanı da farklılaşmaktadır; yeni düzenleme ile büyükşehir belediyeleri daha az vergi alarak daha fazla hizmet götürmek durumunda oldukları geniş kırsal alanlarla karşı karşıyadırlar. Diğer yandan (uygulaması 5 yıl ertelense de) da kırsal alanda yaşayan vatandaş için yeni vergi yükleri ortaya çıkacaktır.

- Sosyal yapıdan kaynaklanabilecek uyum sorunu: Tüzel kişiliği kaldırılan ve mahalleye dönüştürülen köylerin birçoğu farklı kültürel kimlik ve yapı barındırmaktadır. Ülkemizdeki büyükşehir belediyesi karar mekanizmalarına katılım süreçleri incelendiği zaman tüzel kişiliği kaldırılan bu küçük toplulukların ve birimlerin artık karar mekanizmalarına katılımlarının söz konusu olamayacağı beklenebilir. Ayrıca ülkemizde köyler bir yerel yönetim birimi bir hizmet birimi olmanın ötesinde vatandaşlar için bir kimlik ve aidiyet duygusunu sağlayan birimlerdir. Yeni düzenleme ile bu aidiyet duygusu da zedelenebilecektir.

\section{6360 SAYILI KANUN, BÜYÜKŞEHIR DÜZENLEMESİ ÖNCESİ ve SONRASI AYDIN KENTİ}

\subsection{AYDIN İLİNIN GENEL ÖZELLİKLERI}

Aydın kenti tarihin bilinen devirlerinden beri çeşitli uygarlıklara merkez olmuştur. Bugünkü Aydın; kuzeyindeki Top Yatağı sırtında kurulan Trailles Kenti ile birlikte MÖ.2500 yılında Hititler zamanında gelişmiş, VII. yy.da Lydia zamanında da en parlak çağını yaşamıştır. Sırasıyla Neolitik, Kalkolotik, Tunç Çağları ile Frigya, Lidya, Pers, Roma ve Bizans çağlarını, 1171-1270 yılları arasında Selçuklular, 1270-1307 yılları arasında Menteşeoğulları, 1307-1390 yılları arasında Aydınoğulları, 1390-1922 yılları arasında Osmanlı dönemini yaşamıştır. Aydınoğulları zamanında kentin adı Aydın Güzelhisarı olmuş, daha sonra Aydın adını almıştır. Aydın, XIV yy. da bugünkü yerine kurularak idari kademelendirme sırasıyla, 1390 yılında eyalet, 1426 yılında sancak, 1811 yılında eyalet, 1850 yılında İzmir'e bağlı sancak olmuştur. Aydın'ın 1919 yılına kadar sancak şeklinde devam eden bu yönetim şekli, 25 Mayıs 1919-7 Eylül 1922 yılları arasında 40 aya yakın süren işgalden sonra ve Kurtuluş Savaşının kazanılmasıyla birlikte 1923 yılında değişmiş, müstakil vilayet olmuştur (Aydın Ticaret Borsası, 2010: 2).

Bu tarihi dönemlerin ürünü olarak, 1.021 tescilli kültür varlığı olan Aydın'da 8 müze ve 21 ören yeri mevcuttur. Bu ören yerlerinden en önemlileri Afrodisias (Karacasu), Alabanda (Çine), Alinda (Karpuzlu), Apollon Tapınağı (Didim), Gerga (Çine), Harpasa (Nazilli), Magnesia (Germencik-Ortaklar), Mastaura (Nazilli), Milet (Didim), Nysa (Sultanhisar), Priene (Söke), Tralleis (Aydın-Merkez)'dir. 
Aydın, orta ve batı kesiminde verimli ovalar, kuzey ve güneyi dağlar ile çevrili Büyük Menderes Havzası üzerinde 8007 km2 lik bir alan üzerine kuruludur. Doğusunda Denizli, batıda Ege Denizi, kuzeyde İzmir ve Manisa, güneyde ise Muğla illeriyle komşudur.

\section{Şekil 1: Aydın İlçeleri ve Komşu İlleri}

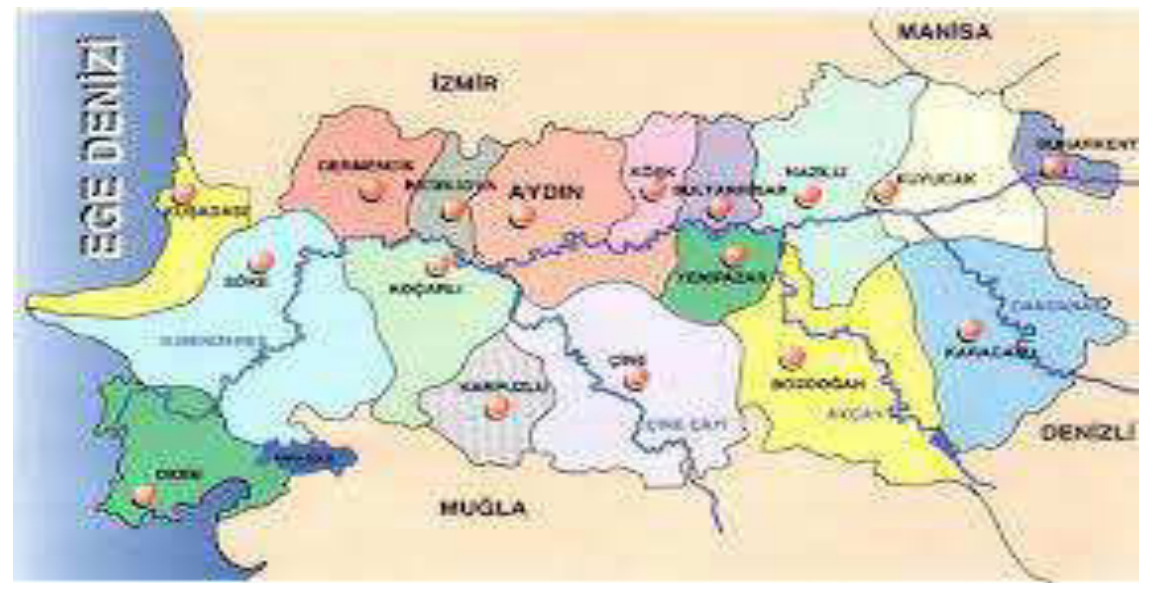

İzmir-Aydın-Denizli Karayolu güzergahında yer alan İl Merkezi, karayolu ve demiryolu ulaşımı açısından kolay ulaşılabilir bir noktada bulunmaktadır. Aydın'da buluna Çıldır Havaalanı küçük uçakların inip kalkmasına elverişlidir, tarifeli uçak seferleri yapılmamaktadır. Aydın'a en yakın Havaalanı, 115 Km mesafede İzmir İlinde bulunan Uluslararası Adnan Menderes Havaalanı'dır. THY Uçuş Okulunun açılmasıyla bu alanda bir ivme oluşmuştur. Aydın'da 1 liman (biri uzunluğu $264 \mathrm{~m}$. diğeri $1435 \mathrm{~m}$ olmak üzere iki iskele) mevcuttur. Aydın İl merkezi hizmetler ve birbiriyle eşgüdüm oluşturan tarım ve tarıma dayalı sanayinin ön planda olduğu bir kent kimliğine sahiptir (TC ÇŞB, 2009). Deniz, termal ve kültür turizmi potansiyeli de Aydın İli'nin diğer öne çıkan yönleridir. Aydın, madenler (feldispat, kuvars, mermer, linyit, kireç taşı, kil), kaliteli kaynak suları, jeotermal enerji kaynakları ve rüzgar enerjisi yönünden de (Didim-Akbük, Söke, Çine'de) zengin bir ildir.

Gelişmişlik sıralamasında Aydın (TR 32) 19. sırada yer almaktadır. Aydın 2010 ve 2011 yılı içerisinde ülke genelinde yapılan kamu yatırımları açısından sırasıyla 25. ve 37. sırada yer almaktadır. Kamu yatırımlarının sektörel dağılımına bakıldığında; yatırımların sırasıyla tarım, diğer kamu hizmetleri, enerji, eğitim ve sağlık alanlarında yoğunlaştığı görülmektedir. 2005 yılına kadar olan süreçte enerji yatırımları liderken özellikle 2007 sonrası tarım desteklerinin arttığı ve temel sektör olarak düşünüldügü izlenmektedir (GEKA, 2013: 65-66). Kentte Adnan Menderes Üniversitesi, bünyesinde barındırdığ 11 fakülte, 6 yüksekokul, 3 enstitü, 16 meslek yüksekokulu, 17 araştırma ve uygulama merkeziyle sanayiye ve üretime her alanda destek vermektedir.

İlin sanayi yapısı; tarım bölgesi olması sebebiyle tarıma dayalı işlenmiş ürünler (tekstil), kimyevi maddeler ve mamulleri (selüloz), bitkisel ürünler (zeytin, zeytinyağı, tütün, yaş sebze ve meyve, vb.) ve sanayi mamullerinden (otomotiv endüstrisi, makine ve makine ekipmanları) oluşmaktadır. Aydın' da faaliyet halinde olan 4 adet Organize Sanayi Bölgesi (OSB) mevcut olup, bunlar Aydın I. (Umurlu) OSB, Aydın II. (ASTIM) OSB, Nazilli OSB ve Ortaklar OSB'dir. Ayrıca gerçekleştirme çalışmaları devam eden Söke, Çine, Buharkent, Çine (Akçaova) için de OSB projesi bulunmaktadır. 2011 y1lı itibariyle Aydın I., Astim, Nazilli, Ortaklar Organize Sanayi Bölgelerinde bulunan toplam fabrika sayıs1 138 adet olup istihdam edilen toplam personel sayıs 5988 kişidir (TC. BSTB, 2012: 60). VF Ege Söke Giyim Sanayi ve Ticaret A.Ş., Söktaş Tekstil Sanayi ve Ticaret A.Ş., Uğur Soğutma Makinaları Tekstil Serigrafi Baskı Maden ve Mermer Sanayi ve Ticaret A.Ş., Gabay Dış Ticaret ve Gıda Sanayi A.Ş., Osman Akça Tarım Ürünleri İthalat İhracat Sanayi ve Ticaret A.Ş İlin önemli sanayi kuruluşlarıdır. Jeotermal elektrik üretiminden arta kalan atık sudan meşrubat ve gazlı içecek sanayinde kullanılmak üzere sıvı karbondioksit imalatı yapabilen Hollanda 
sermayeli Linde Gaz A.Ş. de ilde faaliyet göstermektedir. Çine Ak Maden A.Ş., Kaltun Madencilik A.Ş. ve Esan Eczacıbaşı A.Ş. seramik alanında, MB holding jeotermal alanında ilde faaliyet gösteren firmalarıdır.

1940'lardan itibaren Aydın'da nüfus artışı hızlı bir seyir izlemiştir. Aydın nüfusu, 1935'de 261.078 iken, özellikle kentin tarım potansiyeli nedeniyle yıllar içinde göçlerle ve 1992'de Adnan Menderes Üniversitesi'nin açılmasıyla birlikte artarak 2000'de 950.757'ye yükselmiştir. Yerleşim özellikleri de değişen Aydın İlinde; 1940'lı yıllarda nüfusun yaklaşık \%18'i kent merkezinde yaşarken, 2000 y1lında nüfusun yaklaşı \%70'i kent merkezinde yaşar hale gelmiştir (Genç ve Özgür, 2009; Deniz vd., 2005). İlin toplam şehirleşme oranı \% 60 civarındayken bu oran ilçelere göre farklılıklar sergilemektedir. Örneğin Merkez (\% 74,8), Didim (\% 79,2), Kuşadası (\% 77,1), Nazilli $(\% 75,2)$ ilçelerinde şehirleşme oranı \% 70'in üzerinde değerler alırken Karpuzlu (\% 17), Koçarlı (\% 25,2), Kuyucak (\% 26,4), Bozdoğan (\% 27,6) ilçelerinde \% 28'in altında kalmaktadır. Ancak genel şehirleşme oranları incelendiğinde, ilçelerin kırsal nüfusunun şehir nüfusundan daha yoğun olduğu görülmektedir (GEKA, 2013: 22). TÜíK verilerine göre Aydın İli 2013 yılı itibariyle 1.020.957 kişilik nüfusuyla Ege Bölgesinin büyük illerindendir. 2012-13 döneminde yıllık nüfus artış hızı \%14,2, nüfus yoğunluğu ise 130 'dur. İlçe nüfusu, 510.512; köy nüfusu ise 510.445'tir. Aydın'1n 2012'de 1.006.541 olan nüfusunun 2023'te 1062288'e ulaşması beklenmektedir'.

İlin nüfus yoğunluğu ve şehirleşme oranı Türkiye ortalamasının üstündedir. İl genelinde $\mathrm{km} 2$ ye düşen nüfus 120 kişi, nüfus artış hızı ise \% 0,9 'dur. İl Merkezinde ise km2 ye düşen nüfus 358 iken, Nazilli'de 218, Söke'de 148, Kuşadası'nda 262 ve Didim'de 96'dır. Kuşadası ve Didim İlçeleri deniz kıyısında olması nedeniyle yaz aylarından turizm faaliyetlerinden dolayı nüfus yoğunluğu daha da artmaktadır (TC ÇŞB, 2012: 48).

Tablo 2: Aydın ve İlçe Belediyelerinin Nüfusları ve Yüzölçümleri

\begin{tabular}{|l|l|l|}
\hline & Toplam & Yüzölçümü (km2) $)^{7}$ \\
\hline Aydın & 1.020 .957 & 9352 \\
\hline Bozdoğan & 34.930 & 860 \\
\hline Buharkent & 12.466 & 102 \\
\hline Cine & 51.020 & 915 \\
\hline Didim & 64.643 & 334 \\
\hline Efeler & 265.234 & \\
\hline Germencik & 43.209 & 409 \\
\hline Incirliova & 45.343 & 215 \\
\hline Karacasu & 19.807 & 796 \\
\hline Karpuzlu & 11.777 & 254 \\
\hline Koçarlı & 24.266 & 470 \\
\hline Köşk & 27.152 & 146 \\
\hline Kuşadası & 94.995 & 226 \\
\hline Kuyucak & 27.755 & 499 \\
\hline Nazilli & 148.531 & 666 \\
\hline Söke & 115.541 & 988 \\
\hline Sultanhisar & 21.114 & 237 \\
\hline & & \\
\hline
\end{tabular}

\footnotetext{
${ }^{6}$ http://www.tuik.gov.tr/PreTabloArama.do

${ }^{7}$ http://www.hgk.msb.gov.tr/urunler/diger/il_ilce_alanlari.pdf (4.4.2014)
} 


\begin{tabular}{|l|l|l|}
\hline Yenipazar & 13.174 & 194 \\
\hline Toplam & 1.020 .957 & \\
\hline
\end{tabular}

Kaynak: http://tuikapp.tuik.gov.tr/adnksdagitapp/adnks.zul (18.2.2014)

Tablo 2'ye göre, Aydın Büyükşehir Belediyesinin en yoğun nüfuslu ilçesi, yeni ilçe olarak büyükşehire eklenen Efeler'dir (265.234). Bunun yanında diğer yoğun nüfuslu ilçeler; Nazilli (148.531); Söke (115.541); Kuşadası (94.995); Didim (64.643) dir. Bu kentlerin çoğu ayrıca il içinde gelişmişlik özellikleri ile önde olan yerlerdir.

Turizm ve tarımda istihdam olanaklarına bağlı olarak il merkezine ve ilçelere yoğun göç alan Aydın ili nüfusunun 693.976 kişisinin Aydın İli nüfusuna, il nüfusunun \% 30,5'inin ise farklı bir ilin nüfusuna kayıt olduğu görülmektedir. Aydın İli dışında Denizli (20.496), İzmir (18.081), Ağrı (17.884), Bitlis (15.239), Konya (13.579), Muş (13.526), Afyon (11.977), Erzurum (10.420), Muğla (10.205), Siirt (9.217), Manisa (7.367) nüfusuna kayıtlı nüfusun yoğunluğu dikkat çekmektedir. Buna göre, Aydın'a göçün bir kısmı İzmir ve Denizli'den, ve yoğun olarak Ağrı, Bitlis, Muş, Siirt, Konya, Erzurum'dan gerçekleşmektedir. İlin aldığ1 göçün yanı sıra önemli ölçüde nitelikli göç verdiğini söylemek mümkündür. Aydın ili nüfusuna kayıtlı toplam 903.598 kişinin 693.976 kişisi Aydın'da ikamet etmektedir. Bunun dışında Aydın ilinden çoğunlukla çevre illere ve İstanbul, Ankara gibi büyük şehirlere; İzmir (84.879), İstanbul (25.157), Muğla (23.203), Denizli (15.315), Ankara (10.534), Antalya (6.482), Manisa (4.712), Bursa (3.646), Balıkesir (2.844), Kocaeli (2.297)'ye göç verdiği görülmektedir (GEKA, 2013: 27-28).

\subsection{AYDIN'DA KENTSEL GELİŞME}

Aydın kenti, Orta Menderes Ovasının kuzeyinde, Aydın Dağlarının güney yamacında depremler ve bölgeye hakim olan devletler tarafindan birçok kez yakılıp yıkılmış, ancak Anadolu'yu Ege Denizine bağlayan bir kavşak noktasında olmasından, zengin bir tarım potansiyelinin bulunmasından dolayı her defasından yeniden kurularak M.Ö. 1200'lerden itibaren, Trailles Antik kenti ile başlayarak, Menteşe ve Aydınoğlu beyliklerine ev sahipliği yaparak yerleşim yeri olarak günümüze kadar varlığını sürdürmüştür (Uğur, 2003: 42-48).

\section{Şekil 2: Kuruluşundan 1923 Sonrasına Kadar Aydın Kentinin Gelişimi}

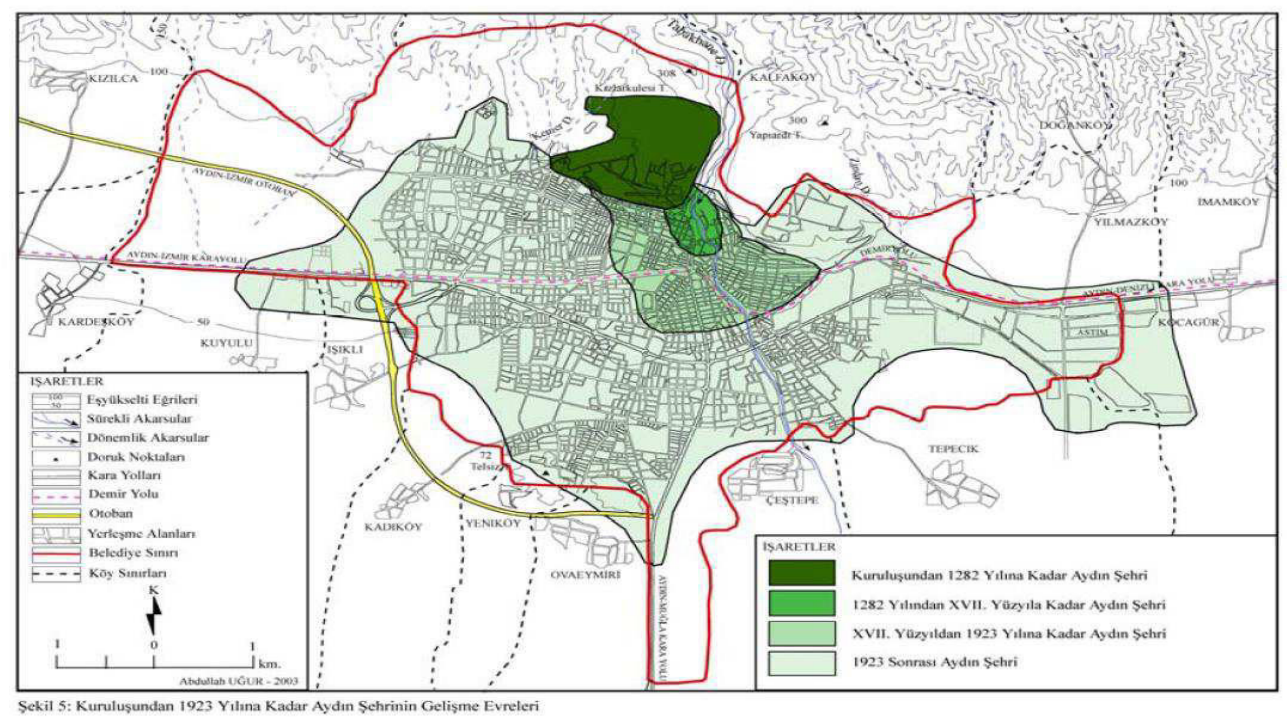

Kaynak: Uğur, 2003: 48. 
Aydın'da ilk imar planı, Yunan işgalinin ardından yanan kenti yeniden imar etmek için 1923 ve 1926 yıllarında dönemin belediye başkanı Fuat Şahin Erlaçin tarafindan hazırlatılan halihazır ve imar planları ile gerçekleştirilmişti. "Yangın yeri Planları" olarak adlandırılan bu planlarla kent 1zgara formunda yeniden düzenlenmiş, buna istinaden 1925 yılında Gazi ve Hürriyet Caddeleri açılmıştı. 1939 yılında yeni bir imar planı hazırlanmış ve 1940'lı yıllarda başlanan yapı kooperatifi ile bugünkü Aytepe Mevkiinde Zafer Mahallesi kurulmuş, bu şekilde kent planlı biçimde doğu ve kuzeye doğru gelişmesini sürdürmüştür. Ardından Pınarbaşı Mesire alanı ile 1923-1050 döneminde yoğun imar faaliyetleriyle kent 175 hektarlık alana yayılmıştır. 1950 ve sonrası süreçte gerek köyden kente göç gerekse 1911 yılından başlayarak kente yurtdışından gelen göçmenler de kentin fiziksel gelişiminde etkili olmuş, Kemer, Mesudiye, Orta Mahalleleri ve o zamana kadar yerleşmeye açılmayan Denizli-İzmir karayolunun güneyindeki Tellidede semti de göçmen konutlarının yapılmasıyla yerleşime açılmıştır (Güneş, 2010: 9). Bu yerleşme yerlerinin yakınlarında başlayan düzensiz ve gelişigüzel kentleşme ile Aydın ilk kez bu dönemden itibaren gecekondulaşma ile karşılaşmaya başlamış, artan nüfus önceden korunan tarım alanlarına doğru, Denizli-Aydın karayolunun güneyine, ovaya doğru yayılmaya başlamıştır. 1951 yılından A. Kömürcü tarafından hazırlanan imar planı, 1959 yılında bu hızlı gelişmeler nedeniyle yenilenmiş̧ir. Orta Mahalle sınırlı içinde Aydın Tekstilin kurulması burada yerleşmeyi daha da hızlandırmış ve Osman Yozgatlı Mahallesi kurulmuş, kentin güneyindeki bu alanda kaçak yapılaşma ve gecekondulaşma giderek yaygınlaşmıştır. Bu gelişme özellikleri 1968 yılında imar planının güncellenmesine neden olmuştur. 1965-70 döneminde yoğun biçimde yurt dışına göç, plan dışı gelişen bu alanların imar ıslah planları ile rehabilite edilmesi fırsatını vermiş, gecekondu önleme bölgeleri (Ilıcabaş1, Kanlıkavak,Kemer, Meşrutiyet Mahallelerinde) oluşturulmuştur. 1971 yılında 2. ve 1978 yılında 3. sanayi sitesinin açılmasıyla bu yönde kentsel gelişme hızlanmış, Girne, Efeler ve Ata Mahalleleri kurulmuştur. 1970-1990 döneminde yapılaşma hızlı nüfus artışı, şehrin kuzeyinin dağlık ve sit alanı olması, güneyin de tarım topraklarından oluşması nedeniyle dikey yönde gelişme hızlanmıştır. $\mathrm{Bu}$ dönemde kat artışlarına imkan veren imar düzenlemeleri, Ata ve Osman Yozgatlı Mahallelerinde plan dışı oluşumlar devam ederken 1983 yılında Esat Turak tarafından yeni bir imar planı hazırlanmış ve kentin yayılma alanı 1150 hektara ulaşmıştır. 1984 yılında İzmir-Denizli karayolunu gelişimine paralel biçimde Yedi Eylül Mahallesi, ASTİM kurulmuş, şehrin Muğla yönünde yapılaşmanın yoğunluğu burada 1989 yılında Adnan Menderes Mahallesinin kurulmasıyla sonuçlanmıştır. 1991 yılında Adnan Menderes Üniversitesi merkez kampüsünün kentin kuzeyindeki Kepez mevkiinde kurulması, bu yöndeki gelişmeyi hızlandırmış, 1992 yılında Ilıcabaşı Mahallesi, yenı dönemde Osman Yozgatlı içinde İstiklal Mahallesi, 1996 yılında da kentin kuzeybatısına gelişimi yönlendirmek için Mimar Sinan ve güneybatıya yönlendirmek için Zeybek Mahallesi kurulmuştur.1996 yılında revizyon imar planı ile planlama çalışmaları sanayi ve ticaret ağırlıklı Zeybek Mahallesini de içine alarak gerçekleştirilmiştir. 2001 yılında Fatih Mahallesinin de eklenmesiyle Aydın, 24 mahalleye sahip olmuştur (Uğur, 2003: 51-56). 


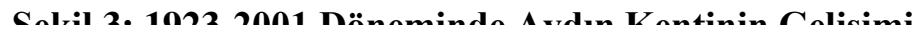

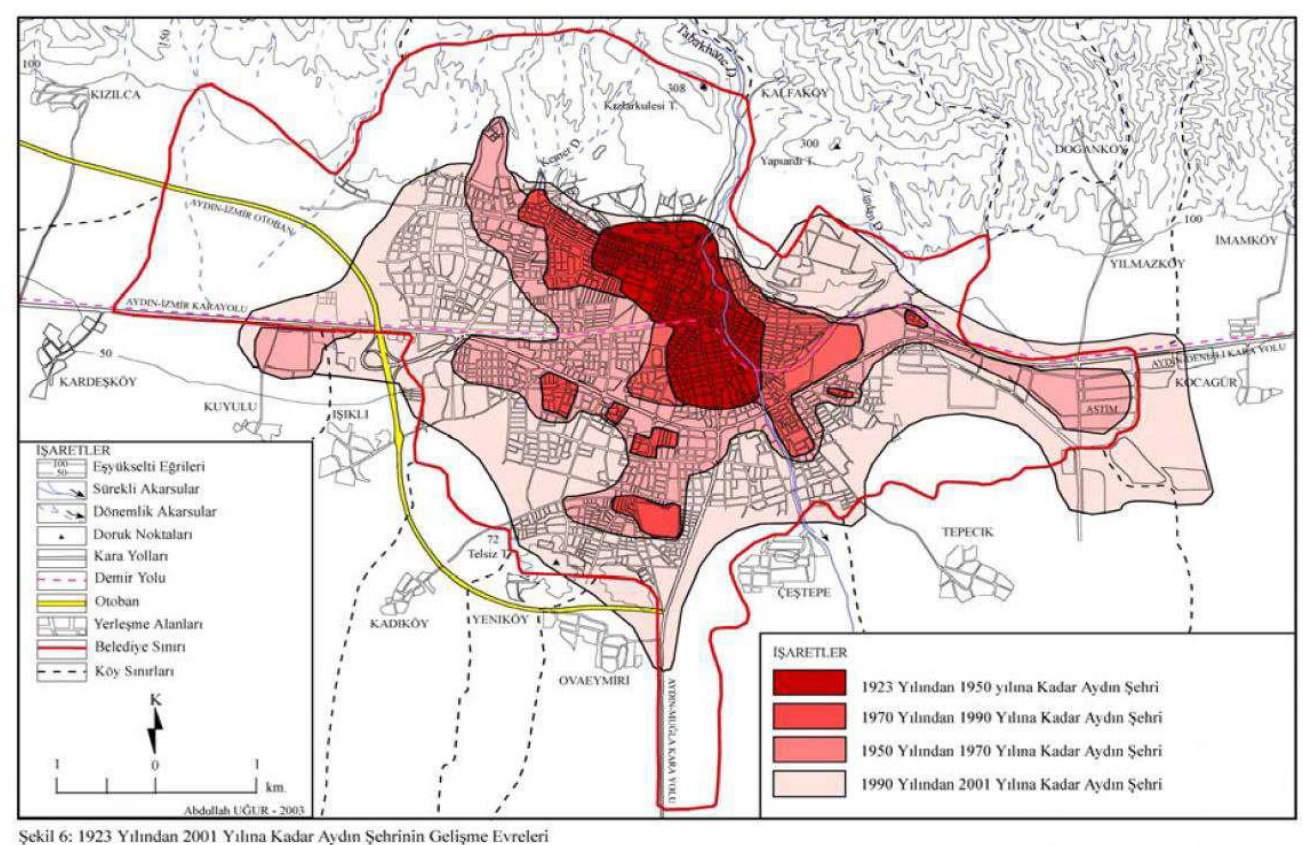

Kaynak: Uğur, 2003: 51

Aydın kenti Türkiye'deki genel kentleşme özelikleri ve sorunları yanında kendine özgü kentleşme özelliklerine de sahiptir. Aydın, göçlerle hızlı ve o ölçüde de plansız biçimde kentleşen, sınırları içinde büyük bir alüvyal ovanın, geniş tarım alanlarının yer aldığı, aktif fay hatları ve jeotermal alanlar üzerinde ${ }^{8}$ yerleşmiş, Kuşadası, Didim gibi önemli turizm alanlarında sahip bir kent olma özellikleriyle öne çıkmaktadır. Aydın kenti ve Aydın kentsel alanı tanımı içinde yer alan yerleşim yerlerinin hemen hepsi Denizli-Aydın-İzmir karayolunun etrafında, ana ulaşım hattına yakın konumda bulunan ve Menderes Nehrinin Kuzeyinde, nehir ve Aydın Dağları arasındaki bölgededir.

Aydın'da, Aydın-Denizli Karayolu aksı üzerinde bulunan Germencik, İncirliova, Merkez, Köşk, Sultanhisar, Nazilli, Kuyucak ve Buharkent İlçeleri bu aks boyunca, birbirleri ile etkileşim halinde, lineer bir gelişme göstermiştir. Bu güzergahta, Aydın Merkez ve Nazilli İlçeleri kentsel çekim merkezleri olarak ön plana çıkmaktadır. İlin, batısında ise Kuşadası, Söke ve Didim İlçeleri arasında Söke merkezli etkileşim ve gelişme eğilimi söz konusudur. Bunun dışında, ilin güney kesimindeki dağlık alanlarda kalan Bozdoğan ve Karacasu İlçeleri kendi etrafında bir gelişim göstermektedirler. Koçarlı'nın merkeze yakınlığı nedeni ile merkezle ilişkili olarak; Yenipazar'ın karayolu üzerindeki yerleşmeler ile etkileşim halinde; Karpuzlu ve Çine'nin ise Çine çekim merkezi olmak üzere kendi içinde gelişme gösterdikleri gözlenmektedir. Çine İlçesi ise yine Aydın İl Merkezi ile etkileşim halinde gelişmektedir.

6360 sayılı kanuna kadar, Aydın İlinin kendisi il merkezli kentsel alan özelliği gösterirken kendi içinde de Aydın merkez ilçe, Söke-Kuşadası (Genç, 2008: 157) ve Nazilli olmak üzere üç kentsel alan özelliği gösteren alt bölgeye sahip olduğu söylenebilir. Hem ilin kendisi hem de bu alt bölgeler, gelişme özelliklerine paralel farklı sorunlarıyla ortaya çıkmaktadırlar.

Kuşadası Türkiye'ye deniz yoluyla çok sayıda turistin giriş ve çıkış yaptığı önemli bir liman kentidir. İzmir Adnan Menderes Hava Limanı'na yakın olması; yüksek tonajlı gemilerin yanaşabildiği uluslararası bir

8 Türkiye'nin jeotermal sahalarının 7 tanesi Aydın'da bulunmaktadır. Bunlar: Ilıcabaş1-İmamköy-Yılmazköy, Germencik-Ömerbeyli-Bozköy, Çamur, Sultanhisar, Salavatlı, Malgaçemir, Gümüş ve Söke Sazlıköy; Buharent-Orakçı; Nazilli-Gedik; Davutlar'dır (GEKA, 2009: 7). 
limana ve yine uluslararası bir yat limanına sahip olması Kuşadası'nı turizm yönünden çok önemli bir nokta haline getirmiştir. Bununla birlikte, Kuşadası önceki yıllarda turizm tesislerine teşvik amacı ile verilen yüksek yapılaşma hakları ile kıyı ve tarım arazilerinin hızla yok edilmesine sahne olmuştur. İlçe ekolojik açıdan da hassas bir bölgede yer almaktadır; bu bölgelerden uluslararası literatüre de geçmiş olanlar Kuşadası-Didim Arası Akdeniz Foku Yaşam Alanları ile Dilek Yarımadası ve Büyük Menderes Deltası Önemli Bitki Alanları'dır. Yerleşimin içinde ve çevresinde önemli kültürel değerler ve sit alanları da bulunmaktadır. Deniz turizmi potansiyeli turizm tesisleri ile ikinci konut oluşumlarının Kuşadası'nda yığılmasına neden olmuştur. 1990'lı yıllara kadar doruklara ulaşan bu talepler, son on yılda hızını yitirmiştir. Günümüzde Kuşadası'na olan talebi yaratan deniz, tarih ve doğa, kontrolsüz kentleşme yüzünden yok olma durumundadır. Son yıllarda oluşan yabancıların mülkiyet edinme talebi, ilçede ikinci bir hızlı yapılaşma dalgası yaratma durumundadır (TC ÇŞB, 2009).

Nazilli Aydın İli'nin hem nüfus hem de sosyo-ekonomik açıdan en gelişmiş ilçesidir. Cumhuriyet'in ilanından sonra Sümerbank Fabrikasıyla Türkiye'de sanayi gelişiminin desteklendiği ilk yerleşmelerden biri olan Nazilli, geniş kapasiteli sanayi kuruluşlarının yanı sıra zeytin, pamuk gibi tarım ürünlerinin işlenmesine yönelik değişik kapasitede pek çok sanayi tesisi ile bir sanayi ve ticaret merkezi haline gelmiştir. Nazilli, 400 yataklı devlet hastanesi, ADÜ Nazilli İ̈BF, yüksekokullarla yaklaşık 7000 öğrencinin yaşadığı bir kenttir. İlçede mevcut bir organize sanayi bölgesi, küçük sanayi sitesi ve konut dışı kentsel çalışma alanları bulunmaktadır. Nazilli İlçesi, Gedik Köyü’ndeki termal kaynaklar ile termal turizm; Mastavra Ören Yeri ile kültür turizmi potansiyeline sahiptir. İlçe Merkezi ile batıdaki Dallıca Köyü arasındaki bölgede, kuzeydoğuda yer alan Arslanlı Mahallesi ile Nazilli İlçe Merkezi'ni birbirine bağlayan yol aksında ve batıda yer alan İsabeyli Mahallesi’ne doğru kentsel gelişme sürmektedir (TC ÇŞB, 2009).

Büyük Menderes Havzası'nda, ilin en geniş ovasında yer alan Söke, ilçe topraklarının büyük bir bölümünün düzlük arazilerden oluşması nedeniyle ilin verimli tarım topraklar bakımından en zengin ilçelerinden birisidir. Söke, aynı zamanda, uluslararası öneme sahip ekolojik açıdan hassas önemli doğa alanlarının bulunduğu bir bölgedir. Bunlar, ilçenin güneyinde, Didim ve Milas İlçeleri sınırındaki Bafa Gölü Önemli Kuş Alanları ve Batı Menteşe Dağları Önemli Bitki Alanları; ilçe sahillerindeki Büyük Menderes Deltası Önemli Kuş Alanları ile Güzelçamlı Milli Parkı'dır. Söke, bu alanlardaki doğa turizmi potansiyelinin yanı sıra, Priene Antik Kenti, Thebai ve Myus Ören Yerleri ile önemli bir kültür turizmi odağıdır. Söke, yakın çevresindeki yerleşmeler, özellikle Kuşadası, Davutlar ve Güzelçamlı için kentsel bir merkez niteliği taşımaktadır. İlçede ticaret ve sanayi gelişmiştir. Söke'de bir organize sanayi bölgesi kurulma çalışmaları devam etmektedir ve bir havaalanı projesi bulunmaktadır (TC ÇŞB, 2009).

Aydın Bilim, Sanayi ve Teknoloji İl Müdürlüğü'ne kayıtlı bulunan 725 sanayi işletmesinin ilçeler bazında dağılımına bakıldığında üretici firmaların ağırlıklı olarak merkez ilçe başta olmak üzere Nazilli, Didim, Söke, Germencik ve Çine'de toplandığı görülmektedir. Sektörel dağılımda ise işletmelerden 305 tanesi gıda imalatı, 87'si tekstil ve 84'ü maden işletmeciliği sektörlerinde faaliyet göstermektedir. Metal, inşaat ve makine sanayi de sıralamada yer alan, sayıları az olsa da yüksek cirolara sahip firmaların olduğu ve özellikle tarım makinaları alanında dünya çapında söz sahibi üreticilerin bulunduğu sektörlerdir (GEKA, 2013: 94).

Turizm belgeli tesislerin ilçelere dağılımı incelendiğinde; kapasitenin tamamına yakınının önemli birer turizm merkezi haline gelen Kuşadası ve Didim'de bulunduğu gözlenmektedir. Buna göre 2011 İl Kültür ve Turizm Müdürlüğü verilerine göre Aydın toplam yatak kapasitesinin \% 95'i bu ilçelere aittir. Kuşadası 65 tesiste toplam 19.009 yatak kapasitesine; Didim ise 19 tesiste toplam 7.085 yatak kapasitesine sahiptir. Aydın'daki bu tesislerin türlerine göre dağılımı incelendiğinde 2 tatil köyünün Kuşadası'nda, 2'si golf tesisi olmak üzere 4 tatil köyünün Didim'de bulunduğu görülmektedir. 1'i Germencik'te olmak üzere 15 adet 5 yıldızlı otel, Karacasu'da 1 adet butik otel ve Kuşadası'nda bir kongre merkezi bulunmaktadır. Termal turizm, Aydın'ın üç ayrı ilçesinde yapılabilmektedir. Kuşadası'nda 140 ve 20 yatak kapasiteli 2 adet, Germencik'te 120 yatak kapasiteli 1 adet ve Buharkent'te 40 yatak kapasiteli 1 adet termal tesis bulunmaktadır (GEKA, 2013: 120). 


\subsection{SAYILI KANUN ÖNCESİ AYDIN'DA KENTLEŞME SORUNLARI ve ALTERNATIF ÇÖZÜMLER}

Aydın ili genelinde en başta yoğun göç, buna bağlı olarak ve kıyı kesimde ikincil konutların yol açtığı düzensiz, verimli tarım alanları üzerinde kentsel gelişme, doğal kaynakların tahribi yanında altyapı başta olmak üzere kamu hizmetlerinin sunumunda aksaklıklara, yetersizliklere neden olmaktadır (Aksu, 2002b; Özaydın, 2001:417; Dölgen ve Alpaslan, 2001: 488).

Kentsel gelişme sürecinde Aydın'da da hem kent içindeki boş alanlarda yapılaşma artmış, hem de kent İzmir-Aydın-Denizli Karayolu çevresindeki verimli tarım alanlarını yerleşim, sanayi ve ticaret alanı haline dönüştürerek, saçaklanmalar yaparak, bu güzergâhtaki ilçe merkezi, belde belediyesi, köylerle giderek yakınlaşarak gelişmiştir. Kent içinde uygun alanların olmaması nedeniyle bazı önemli tesisler de komşu belediye ve köy sınırlarında yerleşmiş, merkeze yakın olan köy ve belediyeler kentle bütünleşmiştir (Deniz ve dig., 2005; Erdem vd, 1999: 57). Aydın İli genelinde iç içe geçmiş çok sayıda belediye ve köyün altyapı ve ulaşım planlanmasının ayrı ayrı yapılmasından kaynaklanan parçalı planlar ortaya çıkmıştır. Sözkonusu alanda yapılan mevcut planların hiçbiri arazi dönüşümleri ve yol açtığı sorunları ortadan kaldırmaya yetmemektedir (Esbah, 2007: 453, 457). Kentin sosyal, çevresel, coğrafî̀ ve ekonomik yapısından kaynaklanan faktörlerin yanısıra kuruluşlar arası koordinasyonsuzluk, çevresel değerleri göz ardı eden, kişisel tercihler, sanayileşmeyi ve karayolu ulaşımını destekleyen politikalar da bu alandaki yönetim sorunlarının diğer nedenleridir (Kılınç, 2000; 2008).

Aşırı nüfus yığılması ve göçler kentleşme ve sanayileşmeye bağlı olarak çevre sorunları da ortaya çıkmaktadır. 1. sınıf sulak alan olan, Büyük Menderes Nehri ve Ovası, Dilek Yarımadası Milli Parkı, Bafa Gölü Tabiat Parkı, Eski Doğanbey Köyü sit alanını kapsayan Büyük Menderes havzasında kentleşme sürecinden kaynaklanan atıklarından, sanayi faaliyetlerinden, maden ve taş işlemeciliğinden oluşan kirleticilerin etkisi görülmektedir. Sözkonusu kirliliğin önlenmesine yönelik planlama çalışmalarında da havzanın bütün olarak planlanma ihtiyacı vardır (Güney, 1999: 15). Son dönemde bunların yanında Beşparmak Dağlarında yoğunlaşan taş ocakları, jeotermal tesislerin açılması ve faaliyete geçmesi ile ortaya çıkan, atık suyun drenajı gibi sorunlar da gündeme gelmeye başlamıştır.

Kırsal yerleşik alanlar ilçe merkezleri dışındaki tüm beldeler ve köyleri kapsamaktadır. Aydın'da kırsal yerleşim alanları mekansal gelişim açısından iki farklı grupta toplanmaktadır. Bunlar sahil ve iç bölgelerde yer alan yerleşimlerdir. Aydın'ın sahildeki turistik ilçeleri Kuşadası ve Didim'e bağlı kırsal yerleşimler ile iç kesimlerdeki yerleşimler arasında belirgin bir gelişmişlik farkı bulunmaktadır. Aydın arazi kullanımında kentsel yerleşim alanları kırsal alanlara göre daha fazladır. 1/100000 ölçekli Aydın-MuğlaDenizli Çevre Düzeni Planı ile kırsal alanlarda yerleşik alan dışındaki konut gelişimlerine yönelik mekânsal gelişmeler dağınık ve düzensiz gelişmeyi önlemek amacıyla kısıtlandırılmış ve böylece tarım toprakları üzerindeki bu yöndeki yapılaşma baskıları da engellenmiştir. Aydın sınırları dahilinde bulunan köylerden özellikle Aydın Merkez ve Nazilli İlçe merkezlerine yakın konumda olanlarda yapılaşma baskısı bulunmaktadır (TC ÇŞB, 2012: 152).

Aydın' da artan gecekondu mahalleleri ve dolayısıyla kentsel yayılma olgusu, tarım arazilerinin amaç dışı olarak kullanılmasına neden olmaktadır. Örneğin, bugünkü ASTİM Sanayi Sitesi, sulu tarım için DSİ Sulama Şebekesi içinde kalan birinci sınıf tarım arazisi idi. Tarım Satış Kooperatifi ile Adnan Menderes Stadı'nın batısı, Devlet Hastanesi'nin batısı zeytinlik ve bağ-bahçe ziraatına tahsis edilmiş arazi konumunda birer tarım arazisi idi. Birinci, İkinci ve Üçüncü Sanayi Siteleri, Kemer Mahallesi'nin içinden geçen Kemer Çayı'nın batısı ve güneyi, bağlık ve incir bahçeleriyle kaplı alanlardı. Bugün, bu bahse konu yerlerde, Adnan Menderes, Ilıcabaşı, Ata, Yedieylül, Efeler, Osman Yozgatlı, Girne Mahalleleri oluşturulmuş durumdadır. $\mathrm{Bu}$ yapılaşmalar, ilk zamanlarda riskli yerleşim bölgeleri teşkil etmiş olmasına rağmen, son zamanlarda Aydın Belediye Başkanlığı tarafından yapılan alt yapı çalışmaları ile sel, heyelan açısından riskli bölge olmaktan çıkartılmıştır. Benzer şekilde Söke'de ilçe merkezi içinden geçen çayın iki yakasındaki meskun yerler, Kuşadası girişindeki Andız Deresi çevresi, Kuyucak İlçesinin kuzeyi, Söke İlçesi'nin Kuşadası çıkışında Abalaki Mevkiindeki yapılaşmalar ve Aydın merkezinde Pınarbaşı mevkiinin batı yamacındaki yapılaşmalar heyelan başta olmak üzere potansiyel tehlikelere açık yerlerdir. Söz konusu yerleşim yerlerinde, 
coğrafi yapıdan dolayı (genel olarak dağların denize dik uzanması ve denizden gelen batı-doğu rüzgarlarının hakim olmasından dolayı) hava kirliliği yönünden risk teşkil etmemektedir. Her büyük ilçe merkezi ile il merkezi, turistik ilçelerden Didim ve Kuşadası civarındaki köylerin yerleşik alanlarına bitişik arazilerde, genelde genişliği (1-2 dönüm) tarım arazileri içine ikinci konut ve daimi yerleşim amaçlı nitelikli konut yapımı talebi artmaktadır (TC ÇŞB, 2012).

İl genelinde kentsel gelişmeyi sınırlayan jeolojik olarak yerleşime uygun olmayan alanlar (Adnan Menderes Üniversitesi Aytepe Kampüsü ve çevresi, Söke Ovası, fay hatları ve bataklık arazileri gibi); Ege Denizi, Dilek Yarımadası Milli Parkı, Söke Ovası vb. gibi doğal eşikler vardır. Bu faktörlerin de etkisiyle Aydın merkezde kent içinde yerleşmesi sakıncalı olan veya gereken büyük ölçekli alanların bulunmaması veya kentsel gelişmeyi sınırlayan insan yapımı yapı stokları nedeniyle belediye sınırları dışına çıkması gereken tesislerin varlığı, Aydın'da havaalanı, Trailles antik kenti, ASTíM ve Umurlu Organize Sanayi Bölgeleri, İzmir Otobanı, asri mezarlık, TARİ̧̧ Sargın Tesisleri, askeri sahalar gibi; Kuşadası, Dilek Yarımadası Milli Parkı, bir yanda Ege Denizi ve diğer yanda Beşparmak Dağlarının sınırlayıcı etkisiyle Davutlar yönünde gelişmektedir. Beşparmak Dağları, Söke Ovası ile sınırlanan Söke'de ise, söz konusu gelişme fay hattı ve heyelan bölgesi olmasına rağmen Kuşadası yönünde sürmektedir. Bunların yanında kentsel sit kapsamında, Söke'de Doğanbey Köyü, Akköy gibi yerleşimler ve Kuşadası'nda, belediye sınırları içinde, imar planı içindeki bazı alanların karakteristik yöresel yapı formu, yasa ve yönetmeliklerle korunmaktadır (Genç, 2008: 162). Büyük Menderes, Dilek Yarımadası Milli Parkı, Kuşadası-Davutlar sahili gibi doğal alanların, içmesuyu havzalarının birden çok belediyeyi ilgilendirmesi nedeniyle ortak planlanması ve yönetilmesi gerekliliği; sözkonusudur.

Aydın merkez ilçe ve Kuşadası-Söke kentsel alanlarında ortaya çıkan yönetim sorunlarını azaltmak veya gidermek için gerek yerel yönetimler gerekse merkezi yönetim tarafindan geliştirilen, bazıları uygulanan bazıları ise sadece fikir bazında kalan çözüm çabaları olmuştur. Bunlardan bazıları şöyle özetlenebilir:

Büyükşehir belediyesi kurmak. 2014 yerel seçimlerinden sonra uygulamaya geçen büyükşehir statüsü, Aydın'da önceki dönemlerde de dile getirilmişti. Aydın Merkez İlçe ile İzmir-Aydın-Denizli Devlet karayolu boyunca Ortaklar Belde Belediyesi, Germencik, İncirliova, Aydın Belediyesi, Umurlu ve Köşk Belde Belediyeleri ile karayolunun iki yanında kalan diğer küçük belediyeler ile birçok köyü kapsayan ve Menderes Nehrinin kuzeyinde kalan bölgede bir lineer büyükşehir belediyesi kurulması fikrini dönemin Aydın Belediye Başkanı Hüseyin Aksu 1997-2000 arasında şekillendirilmiş ve proje kampanya haline getirilerek yasalaşma çabası gösterilmiş, ancak sonuç alınamamıştı (Aksu, 1998: 3). 2002 yılında yine Aksu, Kuşadası-Söke kentsel alanında da bir büyükşehir belediyesi kurulması ve bu kentsel alanın turizm metropolü olarak değerlendirilmesini, Aydın Merkez'de ve Söke-Kuşadası'nda birer büyükşehir belediyesi kurulmasını savunmuştu (Aksu, 2002a; Aksu, 2000b).

İkincisi, merkezi yönetimin KUŞ-ATAK gibi projeleri ve yerel yönetim birlikleri kurmak suretiyle bahsedilen yönetim sorunlarını çözmeye çalışmaktır. Turizm Bakanlığı'nın koordinatörlügünde sürdürülen KUŞ-ATAK Projesi (Kuşadası-Söke-Davutlar-Güzelçamlı Çevre Korunma, Altyapı tesislerini Yapma ve İşletme Birliği) 1993 yılında, Kuşadası, Davutlar, Güzelçamlı Belediyelerinin katılımıyla kurulmuştur. 2003'te Söke'nin, 2007 yılında Akbük, Sazlıköy, Akyeniköy, Savuca, Yenidoğan ve Bağarası'nın eklenmesiyle Birliğe üye belediye sayısı 10'a yükselmiştir (Akdoğan vd., 2008: 440). KUŞ-ATAK dışında sözkonusu alanın yönetim sorunlarını gidermek için kurulmuş olan başka yerel yönetim birlikleri de vardır. Bunlardan bazıları: Kıyı Ege Belediyeler Birliği, Ege Belediyeler Birliği, Sulama ve içmesuyu Birlikleri, Büyük Menderes Havzası Çevre Koruma Birliği, Aydın Tralleis Termal Turizm ve Altyapı Hizmet Birliği, Nazilli ve Çevresi Katı Atık Bertaraf Çevre Hizmet Birliğidir.

Üçüncüsü mücavir alan düzenlemesi ve $1 / 25.000$ 'lik imar planlarını hayata geçirmektir. Mücavir alan genişletmesi ve kentin gelecekteki kullanımları açısından Söke ve Savuca Belediyeleri uygulamalar yapmışlardır. Aydın Belediyesinin çevresinde nüfusu az ama kontrol ettikleri alan hayli geniş olan belediye ve köyler bulunmaktadır. Mücavir alan genişletmesi uygulaması, Aydın için de bazı dönemler gündeme gelmiştir. Eylül 2000'de Aydın Belediyesi mücavir alana almak istediği (İkizdere yönündeki) Kuyulu, Işıklı, Şevketiye, Kardeşköy, Kadıköy, Yeniköy ve Kızılcaköy muhtarları görüşmüş ancak, muhtarlar belediyenin 
su ihtiyacını karşılamak için bu yola başvurduğunu, mücavir alana girmek yerine, belde olmak istediklerini belirterek itiraz etmişlerdi (20.9.2000 tarihli Hürriyet Gazetesi). Birden fazla belediye ve köyü ve/veya genişletilmiş mücavir alanı kapsayan 1/25.000'lik imar planları ile 1/10.000'lik makroform imar planları kentsel alanların yönetimi açısından yeterli olmayan ama önemli bir adım özelliği gösteren uygulamalardır. Örneğin Söke Nazım İmar Planında kentin muhtemel gelişme alanları da belirlenmiş ve burada kentin 19862004 yılları arasında geldiği gelişme noktaları plana dâhil edilmiştir. Bu Planda kentsel gelişmeyi sınırlayan coğrafi koşulların etkisi de net biçimde görülebilmektedir. Planda kentin muhtemel gelişme alanları belirlenirken, kentin coğrafi yerleşiminin özellikleri ve bunun yerleşme ve yapılaşmaya etkisi de ortaya konulmuş, yerleşme / gelişme alanları bu özellikler göz önüne alınarak belirlenmişti (Genç, 2008: 163).

Dördüncüsü, yeni ilçeler kurulması, bazı belediyelerin kapatılması, birleşme ve katma uygulamalarıdır. 2005 yılında TBMM'ye Ortaklar, Bağarası, Umurlu ve Atça adlarında dört yeni ilçe kurulması kanun teklifi sunulmuş, ancak gerçekleşmemişti. Bunların yanında 5747 sayılı kanun uyarınca Germencik'e bağlı Mursallı, Karacasu'ya bağlı Ataeymir, Geyre ve Yenice; Koçarlı'ya bağlı Bıyıklı ve Yeniköy; Kuyucak'a bağlı Başaran ve Kurtuluş, Nazilli'ye bağlı Arslanlı ve Pirlibey, Sultanhisar'a bağlı Salavatlı belde belediyeleri köye dönüştürülmüştür. 5393 sayılı Kanunun 8. ve 11. maddelerine dayanarak, Aydın Belediyesi'nin sınırından itibaren $5 \mathrm{~km}$ mesafedeki Çeştepe, Tepecik, Ovaeymir Belediyeleri ile Yeniköy Aydın Belediyesine katılmışıı (11.06.2008 tarihli Yeni Asır Gazetesi); İsabeyli ve Arslanlı Belediyeleri ile Dallıca, Ocaklı, Bozyurt, Sevindikli, Güzelköy, Durasıllı Köylerinin katılımıla Nazilli Belediyesi sınırları da yeniden belirlenmiştir.

Aydın ilinde, 8 yeni ilçe daha kurulması için kanun teklifi de verilmiştir. 2014 öncesi 17 ilçesi olan Aydın'da, Güzelhisar, Atça, Ortaklar, Umurlu, Bağarası, Davutlar, Acarlar ve Efeler adıyla yeni ilçeler oluşturulması istenmiştir. MHP Aydın milletvekili Ali Uzunırmak tarafından TBMM Başkanlığına sunulan kanun teklifi ile, nüfusu 999 bin kişiye ulaşan Aydın'ın, sınır genişlemeleri nedeniyle de yeni ilçelere ihtiyacı olduğu vurgulanmıştır. Ancak bu kanun teklifi de yasalaşmamıştır.

\subsection{SAYILI KANUNLA AYDIN'DA ORTAYA ÇIKAN DURUM}

6360 sayılı yasayla, Aydın sınırları il mülki idare sınırları olarak düzenlenmiş ve aynı adla büyükşehir belediyesi kurulmuş, il belediyesi büyükşehir belediyesine dönüştürülmüştür. Bu haliyle Aydın Büyükşehir Belediyesinin, 6360 sayılı kanunun genel düzenleme şekline uygun olarak; idari alana paralel biçimde yetki alanı da genişlemiştir. Büyükşehir Belediyesi, il bütününde çevre düzeni, nazım ve uygulama planları açısından planlama yetkilerinin tümüne; mahalleye dönüşen köylerde ticari amaç taşımayan yapılar için tip mimari projeler ve mühendislik projesi yapma/yaptırma yetkisine sahip olmuştur. İlçe belediyeleri de Belediye Kanunu ile kendilerine tanınan, mevzii imar planı uygulamaları, katı atık toplama ve depolama, mezarlıkların bakım onarım ve defin işlemleri, çevre dokusunu koruma, sosyal etkinlikler vb dışında kalan imar uygulaması ve değişiklikleri, toplu taşıma hizmetleri, plaka sınırlaması, tesisleri işletme, kiraya verme, reklam gelirleri ve her türlü fiyat tespit ve ayarlamaları da dâhil yetkilerini büyük şehre devretmiştir.

Aydın Büyükşehir Belediyesinde Efeler adıyla yeni bir ilçe kurulmuştur. Aydın Büyükşehir Belediyesinin kurulmasıyla Aydın İl Özel İdaresinin tüzel kişiliği ortadan kalkmış, Yatırım İzleme ve Koordinasyon Başkanlığı kurulmuştur. Kaldırılan il özel idaresinin yetkileri bakanlıklara, bağlı ve ilgili kuruluşlara, taşra teşkilatına, valiliğe, hazineye, büyükşehir belediyesine, bağlı ve ilgili kuruluşlarına ve ilçe belediyelerine verilmiştir.

6360 sonrası Aydın'da idari yapılanma değişmiştir. Aydın'a bağlı 17 ilçe, Aydın Büyükşehir Belediyesine bağlı ilçe belediyeleri haline gelmiş, bu ilçelerin mülki sınırları içerisinde yer alan köy, belde belediyeleri, bucak ve bucak teşkilatlarının tüzel kişiliği kaldırılmıştır. Bu çerçevede 340'1 orman köyü olmak üzere 490 köyün, 36 belde belediyesinin tüzel kişiliği kaldırılmış ve bunlar Aydın Büyükşsehir Belediyesinin ve ilçe belediyelerinin mahalleleri haline gelmiştir (Tablo 3). 
Tablo 3: 6360 sayılı Kanunla Aydın'da Değişen İdari Yapılanma'

\begin{tabular}{|c|c|c|c|}
\hline $\begin{array}{l}\text { Bağlanılan } \\
\text { İlçe } \\
\text { Belediyesi }\end{array}$ & $\begin{array}{l}\text { Tüzel Kişiliği } \\
\text { Kaldırılan } \\
\text { Belde } \\
\text { Belediyeleri } \\
\end{array}$ & $\begin{array}{l}\text { Tüzel Kişiliği } \\
\text { Kaldırılan } \\
\text { Bucaklar }\end{array}$ & Tüzel Kişiliği Kaldırılan Köyler \\
\hline Bozdoğan & Yazıkent & Merkez & $\begin{array}{l}44 \text { (Akseki, Akyaka, Alamut, Alhisar, Altıntaş, Amasya, Asmaköy, Başalan, Çamlıdere, } \\
\text { Dutağaç, Dümen, Güneyköy, Güneyyaka, Güre, Güvenir, Haydere, Hışımlar, Kalkalan, } \\
\text { Kamışlar, Karaahmetler, Kavakılı, Kazandere, Kemer, Klavuzlar, Kızılca, Kızıltepe, } \\
\text { Konaklı, Koyuncular, Körtepe, Olukbaşı, Osmaniye, Örencik, Örentaht, Ömerpınar, } \\
\text { Örtülü, Pınarlı, Seki, Sırma, Tütüncüler, Yakaköy, Yenice, Yeniköy, Yeşilçam, } \\
\text { Ziyaretli) }\end{array}$ \\
\hline Buharkent & & Merkez & 8 (Ericek, Feslek, Gelenbe, Gündoğan, Kızıldere, Muratdağı, Ortakçı, Savcıllı) \\
\hline Çine & Akçaova & $\begin{array}{l}\text { Merkez } \\
\text { Akçaova }\end{array}$ & $\begin{array}{l}65 \text { (Akdam, Alabayır, Altınabat, Altınova, Bağlarbaşı, Bahçearası, Bedirler, Bereket, } \\
\text { Bölüntü, Bucakköy, Çaltı, Camıză̆llı, Çatak, Çöğülük, Cumalı, Dereli, Doğanyurt, } \\
\text { Dorumlar, Dutluoluk, Elderesi, Esentepe, Eskiçine, Evciler, Gökyaka, Hacıkabasakallar, } \\
\text { Hacıpaşalar, Hallaçlar, Hasanlar, İbrahimkavağı, Kabalar, Kabataş, Kadılar, Kahraman, } \\
\text { Karahayıt, Karakollar, Karanfiller, Kargı, Kasar, Kavşı, Kırkışık, Kırksakallar, } \\
\text { Kızılgüney, Kuruköy, Mutaflar, Ovacık, Özeren, Sağlık, Saraçlar, Sarıköy, Sarnıçköy, } \\
\text { Seferler, Soğukoluk, Söğütcük, Subaşı, Taşoluk, (Tatarmemişler, Tepeköy, Topçam, } \\
\text { Umur, Ünlüce, Yağcılar, Yeniköy, Yeşilköy, Yolboyu, Yürükler) }\end{array}$ \\
\hline \multirow[t]{2}{*}{ Didim } & Akbük & $\begin{array}{l}\text { Akköy, } \\
\text { Merkez }\end{array}$ & \multirow[t]{2}{*}{5 (Akbük, Balat, Batıköy, Denizköy, Yalıköy) } \\
\hline & Akyeniköy & & \\
\hline Efeler & $\begin{array}{l}\text { Çeştepe } \\
\text { Dalama } \\
\text { Ovaeymir } \\
\text { Tepecik } \\
\text { Umurlu }\end{array}$ & Merkez & $\begin{array}{l}53 \text { (Alanlı, Alatepe, Ambarcık, Armutlu, Aşağı Kayacık, Bademli, Balıkköy, Baltaköy, } \\
\text { Böcekköy, Çayyüzü, Çüftlikköy, Dağeymiri, Danişment, Dereköy, Doğan, Eğrikacak, } \\
\text { Emirdoğan, Gödrenli, Gölcük, Gölhisar, Gözpınar, Horozköy, Işıklı, İlyasdere, } \\
\text { İmamköy, Kadıköy, Kalfaköy, Kardeşköy, Kenger, Kırılar, Kızılcaköy, Kocagür, } \\
\text { Konuklu, Kozalaklı, Kuloğulları, Kuyucular, Kuyulu, Mesutlu, Musluca, Ortaköy, } \\
\text { Pınardere, Savrandere, Serçeköy, Sıralılar, Şahnalı, Şevketiye, Tepeköy, Terziler, } \\
\text { Yağcılar, Yeniköy, Yılmazköy, Yukarıyakacık, Zeytinköy) }\end{array}$ \\
\hline \multirow[t]{3}{*}{ Germencik } & Hidırbeyli & Merkez & \multirow{3}{*}{$\begin{array}{l}27 \text { (Abdurrahmanlar, Alangüllü, Balatçık, Bozköy, Çamköy, Çarıklar, Dağkaraağaç, } \\
\text { Dağyeni, Dampınar, Dereköy, Gümüşöy, Gümüşyeniköy, Habibler, Karaağaçl, } \\
\text { Kızılcagedik, Kızılcapınar, Meşeli, Moralı, Naipli, Neşetiye, Ömerbeyli, Reisköy, } \\
\text { Selatin, Tekin, Turanlar, Uzunkum, Uzunlu) }\end{array}$} \\
\hline & Mursalli & Ortaklar & \\
\hline & Ortaklar & & \\
\hline İncirliova & Acarlar & Merkez & $\begin{array}{l}21 \text { (Akçeşme, Arapdere, Arzular, Beyköy, Dereağzı, Eğrek, Erbeyli, Gerenkova, } \\
\text { Hacıaliobası, Hamitler, İkizdere, İsafakılar, Karabağ, Karagözler, Köprüova, } \\
\text { Osmanbükü, Palamutköy, Sandıklı, Sınırteke, Şirindere, Yazıdere) }\end{array}$ \\
\hline \multirow[t]{3}{*}{ Karacasu } & Geyre & \multirow[t]{3}{*}{$\begin{array}{l}\text { Merkez- } \\
\text { Yenice }\end{array}$} & \multirow{3}{*}{$\begin{array}{l}30 \text { (Alemler, Aşağıgörle, Ataköy, Bahçeköy, Bingeç, Çamarası, Çamköy, Dedeler, } \\
\text { Dereköy, Dikmen, Esençay, Görle, Güzelbeyli, Güzelköy, Hacıhıdırlar, Işıklar, } \\
\text { Karabağlar, Karacaören, Nargedik, Palamutçuk, Tekeliler, Tepecik, Yaykın, Yazır, } \\
\text { Yeniköy, Yeşilköy, Yeşilyurt, Yolaltı, Yolüstü, Yukarıörle) }\end{array}$} \\
\hline & Ataeymir & & \\
\hline & Yenice & & \\
\hline Karpuzlu & & Merkez & $\begin{array}{l}19 \text { (Akçaabat, Çobanisa, Cumalar, Ektirli, Gölcük, Güneyköy, Hatipkışlass, Işıklar, } \\
\text { Kovuk, Meriçler, Merkez, Mutluca, Ömerler, Ovapınarı, Şenköy, Tekeler, Ulukonak, } \\
\text { Umcular, Yahşiler) }\end{array}$ \\
\hline \multirow[t]{3}{*}{ Koçarlı } & Biyıklı & \multirow{3}{*}{$\begin{array}{l}\text { Çakırbeyli } \\
\text { Merkez }\end{array}$} & \multirow{3}{*}{$\begin{array}{l}46 \text { (Akmescit, Bağcılar, Birci, Bıyıklı, Boğaziçi, Boydere, Büyükdere, Çakmar, Çallı, } \\
\text { Çeşmeköy, Cincin, Çulhalar, Dedeköy, Dereköy, Esentepe, Evsekler, Gaffarlar, } \\
\text { Gözkayası, Güdüşlü, Hacıhamzallar, Halilbeyli, Haydarlı, Karaağaç, Karacaören, } \\
\text { Karadut, Kasaplar, Kızılcabölük, Kzılkaya, Kullar, Kuşlarbeleni, Meriçler, } \\
\text { Mersinbeleni, Orhaniye, Sabuca, Şahinciler, Sapalan Satılar Köyü, Şenköy , Taşköy, } \\
\text { Tekeli, Timinciler, Tığlılar, Yağcıdere, Yağhanlı, Yeniköy, Zeytinköy. ) }\end{array}$} \\
\hline & Yeniköy & & \\
\hline & Çakırbeyli & & \\
\hline \multirow[t]{2}{*}{ Kuyucak } & Başaran & \multirow{2}{*}{$\begin{array}{l}\text { Horsunlu, } \\
\text { Merkez }\end{array}$} & \multirow{2}{*}{$\begin{array}{l}23 \text { (Azizabat, Başaran, Belenova, Bucakköy, Çamdibi, Çobanisa, Dereköy, Gencelli, } \\
\text { Gencellidere, Horsunlu-Bucak Merkezi, İğdecik, Karapınar, Kayran, Kurtuluş, Merkez, }\end{array}$} \\
\hline & Horsunlu & & \\
\hline
\end{tabular}

${ }^{9}$ Tablonun hazırlanmasında https://www.e-icisleri.gov.tr/Anasayfa/MulkiIdariBolumleri.aspx dan faydalanılmıştır. 


\begin{tabular}{|c|c|c|c|}
\hline & Yamalak & Pamukören & $\begin{array}{l}\text { Merkez, Merkez, Musakolu, Ören, Ovacık, Pamucak, Pamukören-Bucak Merkezi, } \\
\text { Sarıcaova, Sinekler, Taşoluk, Yamalak, Yaylalı, Yeşildere, Yöre, Yukarıyakacık) }\end{array}$ \\
\hline & Kurtuluş & & \\
\hline & Pamukören & & \\
\hline Köşk & & Merkez & $\begin{array}{l}24 \text { (Akçaköy, Baklaköy, Başçayır, Beyköy, Çiftlikköy, Cumadere, Cumayanı, Gökkiriş, } \\
\text { Gündoğan, Güzelköy, Ilıdağ, Karatepe, Ketenyeri, Kıran, Kızılcaköy, Kızılcayer, Koçak, } \\
\text { Menteşeler, Merkez, Mezeköy, Ovaköy, Sarıçam, Uzundere, Yavuzköy) }\end{array}$ \\
\hline Kuşadası & Davutlar & Davutlar & 6 (Caferli, Çınarköy, Kirazlı, Soğucak, Yaylaköy, Yeniköy) \\
\hline & Güzelçamlı & & \\
\hline Nazilli & İsabeyli & & 60 (Apaklar, Arslanlı, Aşağıörencik, Aşağıyakacık, Bağcıllı, Bayındır, Beğerli, Bekirler, \\
\hline & Pirlibey & & $\begin{array}{l}\text { Dualar, Durasıllı, Esenköy, Esentepe, Eycelli, Gedik, Gedikaltı, Güzelköy, Hamidiye, } \\
\text { Hamzallı, Hasköy, Haydarlı,Hisarcık, İsabeyli, Işılklar, Kahvederesi, Karahallı, } \\
\text { Kardeşköy, Kavacık, Kestel, Ketendere, Ketenova, Kırcakll, Kızıldere, Kocakesik, } \\
\text { Kozdere, Kuşçular, Merkez, Mescitli, Ocaklı, Ovacık, Pirlibey, Rahmanlar, Sailer, } \\
\text { Samailli, Sevindikli, Şimşelli, Sinekçiler, Toygar, Uzunçam, Yalınkuyu, Yazırlı, Yellice, } \\
\text { Yukarıörencik) }\end{array}$ \\
\hline Söke & Atburgazı & Atburgazı & 34 (Akçakaya, Akçakonak, Argavlı, Arslanyaylası, Atburgazı, Avcılar, Avşar, Bağarası- \\
\hline & Bağarası & Bağarası & $\begin{array}{l}\text { Gölbent, Güllübahçe-Bucak Merkezi, Güneyyaka, Güzeltepe, Karaatll, Karacahayıt,, } \\
\text { Karakaya, Kaygıll, Kisir, Köprüalan, Merkez, Merkez, Merkez, Nalbantlar, Özbaşı, }\end{array}$ \\
\hline & Güllübahçe & & $\begin{array}{l}\text { Ozbeyyeniköy, Pamukçular, Sarıkemer, Savuca, Sayrakçı, Sazlı, Serçin, Sofular, } \\
\text { Tuzburgazı, Yamac, Yenidoğan, Yeniköy, Yeșilköy, Yuvaca) }\end{array}$ \\
\hline & Sarıkemer & & \\
\hline & Savuca & & \\
\hline & Yenidoğan & & \\
\hline Sultanhisar & Atça & & 11 (Demirhan, Eskihisar, Güvendik, İncealan, Kabaca, Kavaklı, Kılavuzlar, Malgaçemir, \\
\hline & Salavatlı & & \\
\hline Yenipazar & & & $\begin{array}{l}14 \text { (Alioğullar, Çavdarköy, Çulhan, Dereköy, Direcik, Donduran, Eğridere, Hacıköseler, } \\
\text { Hamzabalı, Karaçakal, Karacaören, Koyunlar, Merkez, Paşaköy) }\end{array}$ \\
\hline TOPLAM & 36 & & 490 \\
\hline
\end{tabular}

Böylelikle Aydın Büyükşehir Belediyesi'nin sınırları Buharkent'ten Didim'e, Kapruzlu'dan Bozdoğan'a, Kuşadası'ndan Çine'ye kadar orman köyleri de dâhil olmak üzere genişlemiş, faaliyet alanı il sınırı olan ve 9352 km2 ye ulaşmıştır. Tablo 1'e göre yüzölçümü itibariyle Aydın'ın en büyük ilçeleri Söke, Çine, Bozdoğan, Karacasu, Nazilli'dir. Aydın BŞB artık bu kent ve mahallelerine de hizmet vermek durumundadır. Kullanım hakkı ilçe ve belde belediyelerine ait gayrimenkul, tesis ve araçlar da (Su depoları, itfaiye araçları, otobüs işletmeleri) büyük şehir belediyesine devredilmeye devam etmektedir.

Aydın'ın büyükşehir statüsü kazanması tartışmaları da beraberinde getirmiştir. 6360 sayılı kanunun Aydın'da uygulanmasına ilişkin yapılan değerlendirmelerden bir bölümü olumludur. Aydın kentinde esas gelişme özelliği Aydın-Denizli-İzmir yoluna paralel biçimde, lineer ve birbirine çok yakın hatta iç içe geçmiş biçimde sıralanmıştır. Bu anlamda 6360 öncesinde Aydın'da eleştirilen bu yapılanma özelliğinden kaynaklanan sorunların bir bölümünün kanunla çözümleneceği, yeni büyükşehir genelinde mevcut imar ve planlama sorunlarının azalacağı düşünülmektedir. 6360 sayılı kanunun verdiği yetki ile Aydın İlinin kapsadığı alan bütününün tek bir otorite tarafından üst ölçekli planlarının yapılarak, küçük bölümlerinin, ilçe ve köylerin, kıyı belediyelerinin birbirinden kopuk ve parçalı biçimde ele alınmasının önüne geçilmesi planlama ilkeleri açısından yerinde bir yaklaşımdır. Örneğin yeni kurulan Efeler ilçesine bağlanan Aydın İl Merkezi'ndeki Çeştepe, Ovaeymir ve Tepecik Beldeleri'nin mekansal gelişimi yıllar içinde merkezle bütünleşme eğilimi göstermiştir. Benzer durum Germencik ile Ortaklar ve Mursalli; Kuyucak, Yamalak ve Pamukören; Nazilli ile İsabeyli; Söke ile Savuca ve Yenidoğan, Sultanhisar ve Atça için de geçerlidir. Bu 
ilçe ve belde belediyeler de iç içe geçmiş konumdadır. Diğer yandan Kuşadası-Davutlar aksında belde ve ilçe merkezleri arasında mesafe bulunsa da bu mesafe özellikle kıyı boyunca ikincil konutların birbirine bitişik gelişmesi nedeniyle imar, ulaşım ve altyapı planlarının birlikte yapılmasını gerekli kılmaktadır. Kanunun getirdiği ölçekte, ortak altyapı yatırımları hayata geçirilebilir, kentsel hizmetler birden çok kenti içine alacak şekilde bütünsel olarak planlanabilir; kentlerin gelişim aksları bütünsel olarak ele alınabilir, makro ölçekte planlı ve öngörülebilir hale getirilebilir. Özellikle Kuşadası-Söke, Nazilli ve Aydın merkez ilçede bu türden planlama ve yerleşme sorunlarının yeni düzenleme ile hafifleyebileceği beklenebilir. Diğer yandan büyük alan yönetimi, il düzeyinde fiziki planların yanı sıra ekonomik, sosyal ve kültürel planlamaları da içeren bir "tümleşik stratejik plan” yapılması için de verimli bir zemin sunmaktadır.

6360 sayılı kanuna yönelik getirilen olumsuz eleştirilerden bir bölümü Aydın Büyükşehir Belediyesinde de ortaya çıkabilecek özellikler göstermektedir. En büyük hoşnutsuzluk doğal olarak tüzel kişiliği kaldırılan belde belediyelerinde ve köylerde ortaya çıkmıştır. Söke'de Bağarası, Kuşadası'nda Davutlar, Didim'de Akbük Belde Belediyeleri, kapatılmaları kesinleştikten sonra ilçe olabilmek için yoğun çaba harcamalarına rağmen başarılı olamamışlardır.

Aydın Büyükşehir belediyesinde 6360 sayılı kanunun olumsuz taraflarından birinin görüneceği alanlardan biri de Aydın büyükşehir Belediyesi ve İlçe Belediyelerinin kendi alanlarına yeni eklenen belde belediyesi ve köylere hizmet götürmesinde yaşayacağı muhtemel sıkıntılardır. Aydın Büyükşehir Belediye sınırları içinde Didim, Karacasu gibi yerleşim yerlerinden bazıları il merkezine, büyükşehre oldukça uzaktır. Aydın il özel idaresinin kaldırılmasının sonucu olarak ilin meskûn mahal olmayan arazilerinin en az \%80'ini oluşturan bu kısımlardaki kamu hizmetleri artık Aydın Büyükşsehir Belediyesi tarafından yürütülecektir. Aydın büyükşehir belediyesi, il merkezine uzak Buharkent $(84 \mathrm{~km})$, Bozdoğan $(69 \mathrm{~km})$, Didim (101 km), Kuşadası $(65 \mathrm{~km})$ Karacasu $(85 \mathrm{~km})$ ' nun köy yolları, mesire yerleri vb.ni işletmek, temizlemek, burada düzeni sağlamakla görevli olacaktır. Benzer şekilde kapatılan belde belediyesi ve köylerden bazıları da hem bağlı oldukları ilçe belediyesi hem de büyükşehir merkezine uzaktır. $\mathrm{Bu}$ durumun, yasanın genelinde eleştirildiği gibi, hizmet sunumunda aksamalara yok açabileceği, hizmet sunum maliyetlerini artırabileceği ve yasanın gerekçesinde de belirtilen etkinlik, verimlilik vb amaçlara ulaşmayı güçleştireceği söylenebilir.

Benzer biçimde Aydın'da tüzel kişiliği kaldırılan ve bağlı bulundukları ilçelerin mahallesi durumuna gelen 490 köyden ve 36 beldeden büyük bölümü için sorunların ortaya çıkması muhtemeldir. Bu köylerden bazıları il merkezine çok yakınken bazıları da oldukça uzak hatta coğrafi engelleri de bulunmaktadır. İlçe belediyelerine yakın, bitişik olan Efeler, İncirliova, Umurlu, Köşk, Germencik gibi belediyeler ve köyler için sorun görülmemektedir. Bunlar içinde 150 orman köyünün durumu ayrı incelemeyi gerekli kılmaktadır. Bu durum yeni büyükşehir ilçe belediyelerinin yeni mahalleler haline gelen bu köylere nasıl hizmet vereceği sorusunu gündeme getirmektedir. Özellikle Çine, Efeler, Koçarl1, Nazilli gibi mahalle/eski köy sayısı çok fazla olan belediyeler için hizmet sunumunun daha da zor olacağı beklenebilir.

Sayılan engeller dışında belediyelerin tümünün bu hizmetleri verecek mali güce, teknik ekipmana, personele sahip olma konusunda standart olmamaları da bir başka sorun kaynağıdır. Bu açıdan bakıldığında Aydın Belediyesi ve Nazilli, Kuşadası, Söke, Didim gibi görece büyük belediyelerin daha iyi durumda oldukları ancak yine de büyüyen ölçek ve özellikle de yeni eklenen eski dağ köyleri/yeni mahalleler açısından hizmet götürmede sorunlar ortaya çıkabileceği beklenebilir. Örneğin Nazilli Belediyesi kapatılan ve kendisine mahalle olarak eklenen çoğu da dağ köyü olan yeni mahallelerine hizmet vermek durumundadır. Çınar, Çiner ve Zengin'in (2009: 507-510) Ankara ve Mersin Büyükşehir Belediyelerinde 5216 sayılı kanunun uygulanması ve ölçek genişletme sürecinde yeni eklenen belediyeleri ile büyükşehir belediyelerinin ilişkilerini inceledikleri çalışmalarında, büyükşsehir belediyelerinin ölçeğin genişlemesi sonrasında hizmetleri üstlenmekte isteksiz davrandıkları, bazı hizmetlerin de yapılan protokollerle ilk kademe belediyelerine devredildiğine dikkat çekmektedirler.

Aydın İli genelinde atıksu arıtma tesisi olmayan ilçelerde fosseptik ve kanalizasyon sistemleri kullanılmaktadır. Yalnızca Kuşadası'nda derin deniz deşarjı yapılmaktadır. Ancak tesisler çalıştırma maliyetleri ve personel yetersizliği gibi sebeplerle düzenli olarak işletilmemektedir. Bunun yanında özellikle mevsimsel olarak nüfusu değişkenlik gösteren ilçelerde mevcut altyapının ihtiyacı karşılayamadığ belirtilmektedir. Ayrıca ilde 21 belediyede kanalizasyon mevcut değildir. Bunlar; Didim-Akbük, Akyeniköy; 
Germencik-Hıdırbeyli, Mursallı, İncirliova-Acarlar, Karpuzlu, Koçarl1- Bıyıklı, Yeniköy, KuşadasıGüzelçaml1, Kuyucak-Horsunlu, Kurtuluş; Nazilli-Pirlibey, Söke-Atburgazı, Bağarası, Güllübahçe, Sarıkemer, Sazlı, Yenidoğan, Sultanhisar Salavatlı’dır (GEKA, 2013:162).

6360 sayılı kanunla Aydın'da seçim çevresi büyükşehir belediye başkanlığı açısından ilin tamamı olmuştur. Konuya ilişkin yasada büyükşehir belediye başkanının seçiminde seçim çevresinin, büyükşehir belediye sınırları içinde bulunan orman köyleri de dahil olmak üzere büyükşehir belediye sınırlarından oluşacağı ifade edilmiştir. Büyükşehir belediye meclisi ise belediye hudutları içinde kalan ilçe seçim çevreleri için tespit edilen belediye meclisleri üye sayısının her ilçe için beşte biri alınmak suretiyle bulunacak toplam sayı kadar üyeden oluşmaktadır. Bu sayıların ne olacağ 1 ise oluşturulacak olan ilçelerin nüfuslarına göre ortaya çıkacaktır. Son yerel seçimlerde Aydın ilinde merkez belediye CHP dedir. Yeni düzenleme ile büyükşehir belediye başkanı seçimlerine diğer ilçelerde, köylerde ve beldelerde yaşayanlar da katılmış, ancak sonuç yine mevcut parti lehine olmuştur.

Tablo 4: Aydın'da 2009 ve 2014 Yerel Seçim Sonuçları

\begin{tabular}{|c|c|c|c|c|}
\hline İlçe & 2009 & 2014 & Belde & 2009 \\
\hline \multirow[t]{5}{*}{ AYDIN } & \multirow[t]{5}{*}{ CHP } & \multirow[t]{5}{*}{ CHP } & Çeştepe & AKP \\
\hline & & & Dalama & $\mathrm{AKP}$ \\
\hline & & & Ovaeymir & $\mathrm{AKP}$ \\
\hline & & & Tepecik & CHP \\
\hline & & & Umurlu & AKP \\
\hline EFELER & & CHP & & \\
\hline Bozdoğan & CHP & CHP & Yazıkent & BTP \\
\hline Buharkent & MHP & MHP & - & \\
\hline Çine & CHP & CHP & Akçaova & $\mathrm{AKP}$ \\
\hline \multirow[t]{2}{*}{ Didim } & \multirow[t]{2}{*}{ CHP } & \multirow[t]{2}{*}{ CHP } & Akbük & CHP \\
\hline & & & Akyeniköy & \\
\hline \multirow[t]{3}{*}{ Germencik } & \multirow[t]{3}{*}{ CHP } & \multirow[t]{3}{*}{ MHP } & Hıdırbeyli & CHP \\
\hline & & & Mursallı & CHP \\
\hline & & & Ortaklar & MHP \\
\hline İncirliova & $\mathrm{CHP}$ & MHP & Acarlar & $\mathrm{AKP}$ \\
\hline \multirow[t]{3}{*}{ Karacasu } & \multirow[t]{3}{*}{ CHP } & \multirow[t]{3}{*}{ CHP } & Geyre & AKP \\
\hline & & & Ataeymir & MHP \\
\hline & & & Yenice & CHP \\
\hline Karpuzlu & $\mathrm{DP}$ & MHP & & \\
\hline \multirow[t]{3}{*}{ Koçarlı } & \multirow[t]{3}{*}{ AKP } & \multirow[t]{3}{*}{ CHP } & Biyıklı & $\mathrm{AKP}$ \\
\hline & & & Yeniköy & CHP \\
\hline & & & Çakırbeyli & \\
\hline Köşk & $\mathrm{AKP}$ & $\mathrm{AKP}$ & & \\
\hline \multirow[t]{2}{*}{ Kuşadası } & \multirow[t]{2}{*}{ CHP } & \multirow[t]{2}{*}{ CHP } & Davutlar & DP \\
\hline & & & Güzelçamlı & CHP \\
\hline \multirow[t]{4}{*}{ Kuyucak } & \multirow[t]{4}{*}{$\mathrm{CHP}$} & \multirow[t]{4}{*}{$\mathrm{AKP}$} & Başaran, & $\mathrm{AKP}$ \\
\hline & & & Horsunlu, & $\mathrm{AKP}$ \\
\hline & & & Yamalak, & AKP \\
\hline & & & Kurtuluş & $\mathrm{AKP}$ \\
\hline
\end{tabular}




\begin{tabular}{|c|c|c|c|c|}
\hline & & & Pamukören & AKP \\
\hline \multirow[t]{2}{*}{ Nazilli } & \multirow[t]{2}{*}{ MHP } & \multirow[t]{2}{*}{ MHP } & İsabeyli & AKP \\
\hline & & & Pirlibey & CHP \\
\hline \multirow[t]{7}{*}{ Söke } & \multirow[t]{7}{*}{ CHP } & \multirow[t]{7}{*}{ CHP } & Atburgazı, & CHP \\
\hline & & & Bağarası, & DP \\
\hline & & & Güllübahçe & AKP \\
\hline & & & Sarıkemer & CHP \\
\hline & & & Savuca & DTP \\
\hline & & & Yenidoğan & AKP \\
\hline & & & Sazlı & AKP \\
\hline \multirow[t]{2}{*}{ Sultanhisar } & \multirow[t]{2}{*}{ AKP } & \multirow[t]{2}{*}{ CHP } & Atça, & MHP \\
\hline & & & Salavatlı & MHP \\
\hline Yenipazar & CHP & AKP & & \\
\hline
\end{tabular}

2009 yerel seçimleriyle karşılaştırıldığında iktidar partisinin oylarının diğer partilere kaydığı dolayısıyla düzenlemenin Aydın'da iktidar partisinin aleyhine sonuçlandığı sonucu ortaya çıkmaktadır. Aydın Büyükşehir Belediye Meclisi 80 üyeden oluşmaktadır. Aydın Büyükşehir Belediye Meclisi'ne CHP 37, AKP 22, MHP 20 ve DSP de 1 üye ile temsil edilmektedir. Aydın Büyükşehir Belediye Meclisi'nde 17'si ilçe belediye başkanı olmak üzere toplamda 80 üye görev yapmaktadır. 80 kişilik Büyükşehir Belediye Meclisi'ne ilçe başkanları hariç Efeler ilçesi 7, Nazilli ve Söke ilçeleri 6'şar, Çine, Didim ve Kuşadası ilçeleri 5'şer, Bozdoğan, Germencik, İncirliova, Koçarlı, Köşk, Kuyucak ve Sultanhisar ilçeleri de 3'er, Buharkent, Karacasu, Karpuzlu ve Yenipazar ilçeleri ise 2'şer üye ile yer almaktadır. 9 ilçeden birinci parti olarak çıkan CHP, Büyükşsehir Belediye Meclisi'ne Köşk, Buharkent, Karpuzlu ve Yenipazar ilçelerinden üye yerleştiremezken, 3 ilçede seçimi kazanan AK Parti de, Germencik, İncirliova, Karacasu ve Karpuzlu ilçelerinden üye çıkaramamıştır. MHP ise 5 ilçede seçimi kazanmıştır. DSP ise, sadece Didim'den üye çıkarmıştır. Başkan dahil 81 kişinin bulunduğu Büyükşehir Belediye Meclisi'nde sadece 7 kadın üye yer almaktadır ${ }^{10}$.

Kanunun Aydın'da yerel temsili ne şekilde etkilediği, bu yeni yapılanmanın ortaya çıkaracağ sonuçlar zaman içinde görülecek olmakla beraber, yüzölçümünün büyüklüğü, yerleşim alanlarının dağınıklığı, aralarındaki mesafeler dikkate alındığında adaletli bir temsilin sağlanamayacağı, temsilde önemli sorunların yaşanacağı, meclislerin seçkinci yapısının il sınırlarına kadar yansıyacağı, belli alanlardan gelen meclis üyelerinin bir kümelenmeye neden olabileceği, kırsalın temsil edilemeyeceği genel eleştirileri (Bulut vd, 2013: 155) Aydın kenti için de geçerli olacağa benzemektedir.

Aydın Büyükşehir belediyesinde yeterli kaynakların, araç-gereç ve donanımın ve elbette yeterli sayıda nitelikli kadroların mevcudiyetine bakıldığında; Aydın genelinde büyükş̧ehir yapılanmasına geçişle beraber özellikle tüm ilçeleri koordine etme açısından Aydın büyükşehir belediyesinin ilk dönemde bocalama yaşayacağı beklenebilir. Özellikle merkeze uzak veya coğrafi, fiziki koşullar büyükşehir ilçe belediyelerinde bu durum daha belirgin olabilir.

Aydın içinde her ilçenin gelişme durumu aynı değildir. Bu durumda her ilçe belediyesinden aynı hizmeti beklemek, köylere hizmet götürmeleri beklemek güç olabilecektir. Aydın büyükşehir özelinde bir başka durum, İl genelinde Kuşadası, Didim, Davutlar gibi kıyı kentlerin bulunması ve özellikle bu kentlerde yaz-kış nüfus farkının çok yüksek olmasıdır. Büyükş̧ehir olma öncesinde de ciddi bir sorun olan bu durum, büyükşehir yapılanmasında da devam edeceğe benzemektedir.

\footnotetext{
${ }^{10}$ http://www.aydinhedef.com.tr/siyaset/07/04/2014/buyuksehir-meclisi-sekillendi (2.5.2014)
} 
Tablo 5: Aydın Büyükşehir Belediyesinin Genel Bütçe Vergi Gelirlerinden Alacağı Pay (2011'e göre)

\begin{tabular}{|c|c|c|c|c|c|c|c|c|c|c|}
\hline & $\begin{array}{l}\text { Yüzölç } \\
\text { üm } \\
(\mathrm{km} 2)\end{array}$ & $\begin{array}{l}\text { İl } \\
\text { nüfus } \\
\text { u }\end{array}$ & $\begin{array}{l}\text { GBV } \\
\text { G } \\
\text { (Bin } \\
\text { TL) }\end{array}$ & $\begin{array}{l}\text { GBV } \\
\text { G } \\
(\% 6, \\
\text { BİN T } \\
\text { L)* }\end{array}$ & $\begin{array}{l}\text { Pay Doğr } \\
\text { udan } \\
(\% 60, \text { Bin } \\
\text { Tl) } \\
{[\mathrm{A}]}\end{array}$ & $\begin{array}{l}\text { Pay Havuzdan } \\
(\% 70, \text { Nüfus, } \\
\text { Bin Tl) } \\
{[\mathrm{B}]}\end{array}$ & $\begin{array}{l}\text { Pay Havuzdan } \\
\text { (\%30, Yüzölçüm, } \\
\text { Bin Tl) } \\
{[C]}\end{array}$ & $\begin{array}{l}\text { Bşb İlçelerden Ge } \\
\text { len Pay } \\
\text { (Bin Tl) } \\
\text { (D) }\end{array}$ & $\begin{array}{l}\text { Sk İdareleri } \\
\text { Pay1 } \\
(\text { Bin } \mathrm{Tl}) \\
\text { (E) }\end{array}$ & $\begin{array}{l}\text { Toplam } \\
(\mathrm{Bin} \mathrm{Tl}) \\
(\mathrm{A}+\mathrm{B}+\mathrm{C}+ \\
\mathrm{D}+\mathrm{E})\end{array}$ \\
\hline $\begin{array}{l}\text { AYD } \\
\text { IN }\end{array}$ & 7,943 & $\begin{array}{l}999,1 \\
63\end{array}$ & $\begin{array}{l}797,5 \\
59\end{array}$ & 45,447 & 27,268 & 57,883 & 28,203 & 61,428 & 20,476 & 195,257 \\
\hline
\end{tabular}

Kaynak: TEPAV ${ }^{11}, 2012$

Yeni düzenleme ile Aydın Büyükşsehir Belediyesinin payı artmakla beraber, aynı ölçüde hizmet alanı da artacağından bu yeni mali durumun ortaya çıkaracağı durum zaman içinde değerlendirilebilecektir.

Aydın'ın 30 Mart 2014 yerel seçimleri sonrasında büyükşehir statüsüne geçmesinin ardından kapatılan il özel idarenin mallarının dağıtımıyla alakalı tartışmalar ve ilk büyükşehir belediye meclisinin açılışı ile tartışmalar devam etmektedir. Aydın İl Özel İdaresinin 91 eğitim ve dinlenme tesisi İçişleri Bakanlığı'na devredilmiştir. Germencik'teki termal otel, Kuşadası'nda dinlenme kampı, bir adet otel, İl Özel İdaresi'nin daha önce kullandığı 6 katlı bina, bir kargır apartman, dört katlı sekiz daireli bir apartman, Karacasu'da Yıldız Tepe Restaurant ve 24 dönümlük zeytinlik ile daha bunun gibi birçok gayrimenkul, İçişleri Bakanlığı'na devredilmiştir ${ }^{12}$. İl özel idarenin mallarının dağıtımı sırasında Aydın Büyükşehir Belediye Başkanı muhalefet partisinden olması nedeniyle kendilerine $\% 2$ oranından pay verildiğini, iktidar partisi ile bu oranın $\% 25$ olduğunu ve geri kalanın da diğer ilçe belediyelerine dağıtıldığını iddia etmiştir ${ }^{13}$. Paylaşımda tartışmaya konu olan meselelerden biri Çiftlik jeotermal sahasıdır. Belediyenin de talep ettiğini iddia ettiği bölge İçişleri Bakanlığı'na devredilmiştir. İlçe belediyelerin kentsel hizmetlerinden önemli bölümünün büyük şehre geçmesiyle beraber, Nazilli Belediyesi'nde olduğu gibi taşeron işçilerin fazlalığı ve işten çıkarılmaları gündeme gelmektedir ${ }^{14}$.

Büyükşehir belediyesi ile aynı partiden olmayan ilçe belediyeleri arasında kaynak paylaşımı anlamında sorunların çıkması muhtemeldir.

Tüzel kişiliği kaldırılan köylerde katılımın daha güçleştiği ve uzaklaştı̆ğ söylenebilir. Daha önceden muhtarlıkla ifadesini bulan idare, köyden mahalleye dönüşen yerleşim merkezlerinde halktan daha da uzaklaşmıştır.

\section{SONUÇ}

$\mathrm{Bu}$ makalede 6360 sayılı kanun genel olarak ve Aydın özelinde ortaya çıkardı̆̆ı/olması muhtemel sonuçlar açısından değerlendirilmiştir.

Kanunun eleştirilen yönleri olmakla beraber, planlamada bütünselliği sağlama konusunda hakkı teslim edilmelidir. Diğer yandan, 6360 sayılı yasa pergel yasası ile karşılaştırıldığında daha makul görülmektedir. 6360 sayılı yasa, getirdiği pek çok yenilik yanında, özellikle orta ölçekli kentsel alan özelliği gösteren, yerel yönetimlerde parçalanmış idari alan ve bunun neden olduğu sorunları ortadan kaldırmak için de yeni bir durum ortaya çıkarmıştır. Bu nedenle yeni kanuni düzenleme, bu özellikleri gösteren kentsel alanlardan biri olan Aydın'da kentleşme sorunlarına kısmen çözüm getirme özelliğine sahiptir.

Buna göre, Aydın özelinde birtakım sıkıntılar olmakla beraber, tam anlamıla tüm sorunları ortadan kaldırmamakla beraber, 6360 sayılı kanunun Aydın merkez ve ilçelerinde bazı kentleşme ve yerleşme

\footnotetext{
${ }^{11}$ http://www.tepav.org256.tr/upload/files/haber/1354287682-

2.6360_Sayili_Yasaya_Go01537re_Belediyelerin_Genel_Butce_Vergi_Gelirlerinden_Alacaklari_Paylar.pdf (29.6.2014)

${ }^{12}$ http://www.aydindenge.com.tr/siyaset/30/04/2014/buyuksehire-devredilmeyen-53-sayfalik-gayrimenkul-var (3.5.2014)

${ }^{13}$ http://www.milliyet.com.tr/ozel-idarenin-mallari-siyasileri-birbirine-aydin-yerelhaber-160822/ (3.5.2014)

${ }^{14}$ http://www.sokerehber.com/aydin-haber/buyuksehir-belediyesinde-sikinti-buyuk-h6130.html (3.5.2014)
} 
sorunlarını çözme potansiyeli olduğu sonucuna ulaşılmıştır. Bu anlamda özellikle iç içe geçmiş belediyeler, kıyı alanların planlanması, B. Menderes nehri gibi doğal alanların planlamasının tek elden yapılması ve daha önceden hizmet birlikleri yoluyla yerel yönetim birimleri arasında sağlanmaya çalışılan koordinasyon ev tasarrufun sağlanması beklenmektedir.

Aydın, tarım alanlarının büyüklüğü, turizm ve ulaşım olanakları, barındırdığı genç ve eğitimi nüfus, zengin kültürel mirasıyla büyük bir gelişme potansiyeli taşımaktadır. Aydın'ın büyükşehir yapılması mevcut potansiyelinin harekete geçirilmesi adına önemli ve olumlu bir gelişmedir. Büyükşehir olmak hem kentin kamu yatırımlarından daha çok pay almasını hem de kente yapılacak yatırımların artmasını sağlayacaktır. Ancak büyükşehir ölçeğinde köy sayısının çokluğu, kentsel hizmet alanının büyüklüğü büyükşehir belediyesini zorlayacak etkiler yapabilecektir. 


\section{KAYNAKÇA}

AKDOĞAN, F., A. GÜNBEY ŞERIFOĞLU, C. CEVAHIR (2008) "Kuşadası, Davutlar, Güzelçamlı, Söke Çevre Koruma, Altyapı Tesislerini Yapma Ve İşletme Birliği, (KUŞ-ATAK Belediyeler Birliği) Altyapı Çalışmaları", F. N. Genç, A. Yılmaz, H. Özgür (Editörler), Dönüşen Kentler, Değişen Yerel Yönetimler, Gazi Kitabevi, Ankara, s. 437-452.

AKSU, H. (2002a) Bağımsız Milletvekili Adayı Hüseyin Aksu'nun 3 Kasım 2002 Seçim Beyannamesi: Kuşadası İlçesi.

AKSU, H. (2002b) Bağımsız Milletvekili Adayı Hüseyin Aksu'nun 3 Kasım 2002 Seçim Beyannamesi: Söke İlçesi.

AKSU, H. (1998) "Aydın Büyükşsehir Olmalı", Yeni Aydın (Gazetesi), Aydın Belediyesi, Yı1 1, Sayı 5, Temmuz, s.3.

ARIKBOĞA, E. (2007) “Büyükşehirlerde Kararları Kim Alıyor? Büyükşehir Belediye Meclislerinde Temsil

Sorunu ve Çözüm Önerileri”, Çağdaş Yerel Yönetimler, Cilt 16, Sayı 1, ss: 31-54.

ARIKBOĞA, E. (2013) “Geçmişten Geleceğe Büyükssehir Belediye Modeli”, Yerel Politikalar, Y11 1, Say1 3, ss: $48-96$.

AYDIN TICARET BORSASI (2010) Aydın Ticaret Borsası Stratejik Planı (2010-2012 Dönemi)

file:///C:/Users/ACER/Desktop/stratejik-plan.pdf (29.6.2014)

BULUT, Y., S. KARAKAYA, A. AYDIN, M. TAMER (2013) "Büyükşehir Yönetimlerinde Ölçeğin Yerel Temsil Üzerindeki Etkisi: Hatay'da Bir Uygulama”, Kuramdan Uygulamaya Yerel ve Kentsel Politikalar (Ed. Yakup Bulut, Veysel Eren, Sedat Karakoç, Abdullah Aydın), Pegem, ss: 151-164.

ÇINAR, T., C. U. ÇİNER, O. ZENGİN (2009) "Metropoliten Alanlarda Bütünleştirme ve Ulusal Kalkınma",

Ulusal Kalkınma ve Yerel Yönetimler-4.Yerel Yönetimler Sempozyumu Bildirileri, Desen Ofset, Ankara, ss:498- 511.

ÇUKURÇAYIR, M. A. (2012) “Yeni Büyükşehir Kanunu Haberleri Türkiye’nin Kabusu”, http://www.yenimeram.com.tr/yeni-buyuksehir-belediyeleri-kanunu-haberleri-turkiyenin-kabusu-

2647yy.htm (3.5.2014)

DENIZ B., TUNÇAY, H. ESBAH, KÜÇÜKERBAŞ, E. V. (2005) "Determination of the Land Use Change Pattern: The Case of City of Aydin, Turkey”, (sözlü bildiri), X. European Ecological Congress, Kuşadas1, Türkiye, 08/11/2005.

DENIZ, T., G.KANTÜRK YIĞIT (2013) “İdari Coğrafya Açısından Büyükşehir Belediyeleri”, The Journal Of Academic Social Studies, Vol \&, Issue 2, pp.: 629-649.

DÖLGEN, D., M. N. ALPASLAN (2001) "Kuşadası Beldesi Alt Yapı Sistemlerinin Gelişim Sürecinin Incelenmesi”, Ayşe G. Şerifoğlu (Editör), Geçmişten Geleceğe Kuşadası Sempozyumu, 26- Şubat 2000, Kuşadas1, Kuşadası Belediyesi, s. 487-492.

DURU, B. (2013) “Büyükşehir Düzenlemesi Ne Anlama Geliyor?”, GAP Belediyeler Birliği Dergisi, MayısHaziran-Temmuz 2013, s: 33-37.

ERDEM, Ü., E. NURLU, R. YILMAZ VE İ. M. KAHRAMAN (1999) "Büyük Menderes Havzas1 Temelinde Aydın İli Alan Kullanım Kararları Üzerine Bir İrdeleme”, 20000'e Bir Kala Büyük Menderes Havzası 4. Tarım ve Çevre Sorunları Sempozyumu, 9-10 Eylül 1999, Söke, İzmir: Ege Üniversitesi Basımevi, s. 49-57.

ERSOY, M. (2013) 6360 Sayll Yasa Ve Mekansal Planlama Sorunları”, GAP Belediyeler Birliği Dergisi, Mayis-Haziran-Temmuz 2013, s: 20-32. 
ESBAH, H. (2007) "Land Use Trends During Rapid Urbanization of the City of Aydin, Turkey", Environ Manage, Sayı: 39, s. 443-359.

Güney Ege Kalkınma Ajansı (GEKA) (2009) TR32 Düzey 2 Bölgesi (Aydin, Denizli, Muğla) Jeotermal Kaynaklari Ve Jeotermal Enerji Santralleri Araştirma Raporu

http://geka.org.tr/yukleme/dosya/5f60844e55155eb66280abe69e42aa51.pdf (2.5.2014)

Güney Ege Kalkınma Ajansı (GEKA) (2013) Aydın 2013-Aydın İl Stratejik Planı

http://geka.org.tr/yukleme/planlama/Strateji\%20D\%C3\%B6k\%C3\%BCmanlar\%C4\%B1/Ayd\%C4\%B1n\%2 02023\%20Stratejik\%20Plan\%C4\%B1\%20Taslak.pdf (6.7.2014).

GÜLER, B. A. (2012a) "Hükümetin 8 Ekim 2012 Günlü Büyükşehir Yasa Tasarısl Üzerine" http://www.yayed.org/uploads/yuklemeler/B\%C3\%9CT\%C3\%9CNSEH\%C4\%B0RTASARIBAG.pdf (3.5.2014)

GÜLER, B. A (2012b) "Büyükşehir Kanun Tasarısı İçişleri Komisyonunda Görüşülüyor”, http://www.yayed.org/uploads/yuklemeler/B\%C5\%9EB\%20KOM\%C4\%B0SYONDA.pdf (3.5.2014)

GENÇ, F. N (2008) "Söke Kentsel Alanı ve Bu Alanın Yönetimi”, F. N. Genç, A. Yılmaz, H. Özgür (Editörler), Dönüşen Kentler, Değişen Yerel Yönetimler, Gazi Kitabevi, Ankara, s. 143-170.

GENÇ, F. N. (2014) “Kentleşme Politikalarının Değişen Yüzü: Gecekondu Yıkımından Kentsel Dönüşüme”,

Adnan Menderes Üniversitesi Sosyal Bilimler Enstitüsü Dergisi, Cilt 1, Sayı 1.

GENÇ F. N., ÖZGÜR H. (2009) "Orta Ölçekli Kentsel Alanların Yönetimi: Aydın Merkez İlçe ve

Kuşadası-Söke Örnekleri”, TODAİE-4. Yerel Yönetimler Sempozyumu, 289-300, Desen Ofset, Ankara.

GÖRMEZ, K. (2012) "Yerelleşme-Merkezîleşme Geriliminde Büyükşehir Yasası"

http://www.zaman.com.tr/yorum_yerellesme-merkezilesme-geriliminde-buyuksehir-yasasi_2017227.html

GÖZLER, K. (2013) "6360 Sayıl Kanun Hakkında Eleştireler: Yirmi Dokuz İlde İl Özel İdareleri ve

Köylerin Kaldırılması ve İlçe Belediyelerinin Büyükşehir İlçe Belediyesi Hâline Dönüştürülmesi Anayasamiza Uygun Mudur?” http://www.idare.gen.tr/6360-elestiriler.pdf

GÜL, H., S. BATMAN (2013) "Dünya ve Türkiye Örneklerinde Metropoliten Alan Yönetim Modellleri ve 6360 Sayılı yasa", Yerel Politikalar, Y11 1, sayı 3,7-47.

GÜNEŞ, G. (2010) “Taşradan Meşrutiyet'e Bakış: 2. Meşrutiyet Döneminde Aydın Sancă̆ı”, Cumhuriyet Tarihi Araştırmaları Dergisi, Y11 6, Sayı 11, s: 5-44.

GÜNEY, A. (1999) “Çevre ve Kalkınma İkileminde Söke: Bütünsel Yaklaşımla Çözüm Önerileri”, 20000’e Bir Kala Büyük Menderes Havzası 4. Tarım ve Çevre Sorunları Sempozyumu, 9-10 Eylül 1999, Söke, İzmir: Ege Üniversitesi Basımevi, s. 7-18.

İCI, F., M. TURAN (2013) “Türkiye'de Büyükşehir Belediye Sistemi ve 6360 Sayılı Yasa İle Büyükşehir Belediye Sisteminde Meydana Gelen Değişimler: Van Örneği”, Süleyman Demirel Üniversitesi İ̈BF Dergisi, C.18, S. 1, s.: 117-152.

KELEŞ, R. (2012a) "Yeni Anakent (Büyükşehir) belediyeşeri Oluşturulmalı mı?”, Yerel Politikalar, Yı1 1, Say1 2, 7-12.

KELEŞ, R. (2012b) “Anakentin Dünü, Bugünü ve Yarını” Kentsel ve Bölgesel Araştırmalar Sempozyumu-3, 6-7 Aralık, Gazi Üniveristesi, Ankara.

KELEŞ, R. (2013) “Anakent Belediyelerinin Sayısı Çoğalırken”, GAP Belediyeler Birliği Dergisi, MayısHaziran-Temmuz 2013, s: 15-19. 
KILINÇ, G. (2000) Ribbon Developments in Aydın along İzmir-Denizli Highway (İzmir-Denizli Karayolu Boyunca Aydın'da Kentsel Gelişmeler), (Yayımlanmamış Yüksek Lisans Tezi), İzmir Yüksek Teknoloji Enstitüsü, Mühendislik ve Fen Bilimleri Enstitüsü.

KILINÇ, G. (2008) “Aydın’da Ana Akslar Boyunca Gelişmenin Yapısı ve Etkileri”, F. N. Genç, A. Yılmaz, H. Özgür (Editörler), Dönüşen Kentler, Değiş̧en Yerel Yönetimler, Gazi Kitabevi, Ankara, s. 393-411.

KOYUNCU E.,T.KÖROĞLU (2012) “Büyükşehir Tasartsl Üzerine Bir Değerlendirme”, TEPAV, www.tepav.org.tr.

ÖZAYDIN, G. (2001) "Kıyı Yerleşmeleri Özelinde Kimlik Değerlerini Sürdürülebilir Kılacak Tasarım Ölçütleri”, Ayşe G. Şerifoğlu (Editör), Geçmişten Geleceğe Kuşadası Sempozyumu, 26- Şubat 2000, Kuşadas1, Kuşadası Belediyesi, s. 415-422.

ÖZGÜR, H. (2005) “Türkiye'de Orta Ölçekli Kentsel Alanların Yönetimi Sorunu”, H. Özgür ve M. Kösecik (Editörler), Yerel Yönetimler Üzerine Güncel Yazılar -I: Reform içinde, Ankara, Nobel Kitabevi, s. 471499.

ÖZGÜR, H. (2007) “Orta Ölçekli Kentsel Alanların Yönetimine İlişkin Alternatifler”, H. Özgür ve M. Kösecik (Editörler), Yerel Yönetimler Üzerine Güncel Yazılar -II: Uygulama, Nobel Yayın Dağıtım, Ankara, s. 100-142.

ÖZGÜR, H.(2008) "Belediye Sayısının Azaltılmasının Tarihsel Sürecine Dair Bir Deneme”, Yerel Siyaset Dergisi, Mart 2008, ss.43-50.

Parlak, B.(2013) "Yeni Büyükşehir Yasasının Analizi”, http://www.bursayerelyonetim.com/index.php/yenibuyuksehir-belediye-yasasinin-analizi/\#sthash.jbyElZdC.dpuf (3.5.2014)

T.C. ÇEVRE VE ORMAN BAKANLIĞI ÇEVRESEL ETKİ DEĞERLENDIRMESİ VE PLANLAMA GENEL MÜDÜRLÜĞÜ (2009) Aydın-Muğla-Denizli Planlama Bölgesi 1/100.000 Ölçekli Çevre Düzeni Planı Raporuhttp://www.csb.gov.tr/db/mpgm/editordosya/file/CDP_100000/amd/amd_PLAN_ACIKLAMA_RAP ORU.pdf (29.6.2014)

T.C. ÇEVRE VE ORMAN BAKANLIĞI, AYDIN VALİİĞİ ÇEVRE VE ŞEHIRCILİK MÜDÜRLÜĞÜ (2012) Aydın İli Çevre Durum Raporu Aydın, 2012.

http://www.csb.gov.tr/turkce/dosya/ced/icdr2011/aydin_icdr2011.pdf (29.6.2012)

T.C. BILIM, SANAYİ VE TEKNOLOJİ BAKANLIĞI (2012) 81 İl Durum Raporu.

http://www.izmiriplanliyorum.org/static/upload/file/bilim_sanayi_ve_teknoloji_bakanligi_81_il_durum_rapo $\underline{\text { ru_(2012).pdf }}(29.6 .2014)$

TEPAV (2012) 6360 Sayılı Yasaya Göre Belediyelerin Genel Bütçe Vergi Gelirlerinden Alacakları Paylar http://www.tepav.org.tr/upload/files/haber/1354287682-

2.6360_Sayili_Yasaya_Gore Belediyelerin_Genel_Butce Vergi_Gelirlerinden_Alacaklari_Paylar.pdf

TÜZÜN, S. (2012) “İki Seçim, 29 Büyükşehir ve Birkaç Saptama” Bianet.

http://ww.bianet.org/bianet/belediye/142129-iki-secim-29-buyuksehir-ve-birkac-saptama (29.6.2014).

UĞUR, A. (2003) “Aydın Şehrinin Kuruluşu ve Gelişme Evreleri”, Coğrafi Bilimler Dergisi, 1 (2), 41-52.

YAYED (2012) “10 Temmuz 2004 Tarih Ve 5216 Sayılı Büyükşehir Belediye Kanunu’nu Değiştiren Büyükşehir-Bütünşehir Tasarısı Hakkında YAYED Görüşü” (11 Ekim 2012)

http://www.sendika.org/2012/10/degistirilen-buyuksehir-butunsehir-tasarisi-hakkinda-yayed-gorusu/ (4.7.2014).

YILDIRIM, U., A. BELLİ (2013) "Yeni Büyükşehir Belediyesi Yönetim Modelinin Metropoliten Alan Kavramı Açısından Değerlendirilmesi”, Kuramdan Uygulamaya Yerel ve Kentsel Politikalar (Ed. Yakup Bulut, Veysel Eren, Sedat Karakoç, Abdullah Aydın), Pegem, ss: 97-111 